Research article

\title{
Further discoveries in the ever-expanding genus Begonia (Begoniaceae): fifteen new species from Sumatra
}

\author{
Mark HUGHES ${ }^{1, *}$, Deden GIRMANSYAH ${ }^{2}$ \& Wisnu Handoyo ARDI ${ }^{3}$ \\ ${ }^{1}$ Royal Botanic Garden Edinburgh, 20a Inverleith Row, EH3 5LR, UK. \\ ${ }^{2}$ Herbarium Bogoriense, Botany Division, Research Center for Biology, \\ Indonesian Institute of Sciences, Cibinong Science Center (CSC), \\ J1. Raya Jakarta-Bogor Km 46, Cibinong, Bogor 16911, Indonesia. \\ ${ }^{3}$ Center For Plant Conservation-Bogor Botanic Garden, \\ Jl. Ir. H. Juanda No.13, P.O.Box 309, Bogor 16003, Indonesia. \\ ${ }^{*}$ Corresponding author: m.hughes@rbge.ac.uk \\ ${ }^{2}$ Email: deden bo@yahoo.com \\ ${ }^{3}$ Email: wisnu.handoyo.ardi@lipi.go.id
}

\begin{abstract}
Fifteen new species of Begonia L. from Sumatra are described and illustrated, in Begonia sect. Bracteibegonia (B. beludruvenea M.Hughes sp. nov. and B. jackiana M.Hughes sp. nov.), $B$. sect. Petermannia (B. harauensis Girm. sp. nov.), B. sect. Platycentrum (B. leuserensis M.Hughes sp. nov.), B. sect. Reichenheimia (B. fluvialis M.Hughes sp. nov., B. halabanensis M.Hughes sp. nov., B. karangputihensis Girm. sp. nov., B. kemumuensis M.Hughes sp. nov., B. korthalsiana Miq. ex M.Hughes sp. nov., B. kudoensis Girm. sp. nov., B. lilliputana M.Hughes sp. nov., B. olivacea Ardi sp. nov., B. raoensis M.Hughes sp. nov., B. simolapensis Ardi sp. nov.) and B. sect. Sphenanthera (B. pseudoscottii Girm. sp. nov.). Using the International Union for the Conservation of Nature criteria, 6 are considered to be Least Concern, 5 Vulnerable and 4 Data Deficient. A key to 58 of the 63 currently accepted Begonia species in Sumatra is provided.
\end{abstract}

Key words. Begonia, new species, limestone, Sumatra, taxonomy.

Hughes M., Girmansyah D. \& Ardi W.H. 2015. Further discoveries in the ever-expanding genus Begonia (Begoniaceae): fifteen new species from Sumatra. European Journal of Taxonomy 167: 1-40. http://dx.doi. org/10.5852/ejt.2015.167

\section{Introduction}

Begonia L. (Linnaeus 1753) is a pan-tropical genus of often shade-loving herbs and shrubs, with a number being very popular horticulturally. The number of accepted species in Begonia currently stands at 1803 (Hughes et al. 2015) with Southeast Asia proving to be particularly rich and yielding substantial numbers of new taxa (e.g. Ardi et al. 2013; Averyanov \& Nguyen 2012; Chong et al. 2015; Hughes \& Takeuchi 2015; Sang et al. 2013; Sang et al. 2015). In Sumatra alone, since the first baseline count of 45 species was published (Hughes 2008) a further 25 endemic species are now known (this study; Ardi \& Hughes 2010; Girmansyah 2012; Hughes et al. 2009). This paper describes fifteen new species from Sumatra, 
in Begonia sect. Bracteibegonia A.DC. (de Candolle 1859) (B. beludruvenea M.Hughes sp. nov. and B. jackiana M.Hughes sp. nov.), B. sect. Petermannia (Klotzsch) A.DC. (de Candolle 1859) (B. harauensis Girm. sp. nov.), B. sect. Platycentrum (Klotzsch) A.DC. (de Candolle 1859) (B. leuserensis M.Hughes sp. nov.), B. sect. Reichenheimia (Klotzsch) A.DC. (de Candolle 1859) (B. fuvialis M.Hughes sp. nov., B. halabanensis M.Hughes sp. nov., B. karangputihensis Girm. sp. nov., B. kemumuensis M.Hughes sp. nov., B. korthalsiana Miq. ex M.Hughes sp. nov., B. kudoensis Girm. sp. nov., B. lilliputana M.Hughes sp. nov., B. olivacea Ardi sp. nov., B. raoensis M.Hughes sp. nov., B. simolapensis Ardi sp. nov.) and B. sect. Sphenanthera (Hassk.) Warb. (Warburg 1894) (B. pseudoscottii Girm. sp. nov.). These are not merely variants of previously known species complexes, but in many cases strikingly distinct growth forms not before recorded on the island, such as the rheophytic B. fluvialis and B. lilliputana, and the succulent-stemmed B. kudoensis. Following the synonymisation of some names (Hughes \& Girmansyah 2011a) and the removal of some dubious records, we consider the total number of currently accepted names in Begonia for Sumatra to be 63, and a key to the majority of these and the five sections they represent is provided below.

The level of narrow endemism is very high, in particular for the limestone species, and many are known from a single collection or population. When species distributions are so limited, extinction of some of the species newly described here within our lifetime is a high possibility - we must strive not to make it an inevitability. Gunung Leuser National Park is under immense pressure from illegal logging and accelerating land use change (Kelman 2013), which has the potential to affect B. leuserensis, B. lilliputana, B. olivacea and B. simolapensis, and the type and only locality for B. karangputihensis is near a massive limestone quarry near Padang and is therefore under threat from mining expansion. In addition to the first priority of in situ habitat preservation, specialist ex situ collections such as those held in Bali Botanic Gardens, Bogor Botanic Gardens and the Royal Botanic Garden Edinburgh have a high potential for playing an important role in the conservation of narrowly endemic Begonia species.

\section{Materials and methods}

The descriptions and other data in this study are derived from herbarium material (both loans and material collected by the authors) and field observations by the authors during a series of expeditions to Sumatra from 2007 to 2011. All Begonia material from Sumatra in ANDA, B, BM, BO, E, FI, K, L, P, SING has been consulted, along with representative loans from A and MICH, 1431 sheets in total. Stable links (Hyam et al. 2012) to images of specimens held in E are included as hyperlinks in this document. Images of most other specimens cited are available from Hughes et al. (2015). All available type material and protologues of Begonia species from Sumatra and surrounding regions has been examined in order to confirm the novelty of the species described. Measurements are derived from dried specimens and hence will deviate slightly from those in the field. Colour and shape descriptions were recorded from digital photographs taken during expeditions and from material in cultivation in the Centre for Plant Conservation, Bogor, Cibodas Botanic Garden and the Royal Botanic Garden Edinburgh, where available. 


\title{
Results
}

\author{
Class Equisetopsida C. Agardh (Agardh et al. 1825) \\ Subclass Magnoliidae Novák ex Takht. (Takhtajan 1967) \\ Superorder Rosanae Takht. (Takhtajan 1967) \\ Order Cucurbitales Juss. ex Bercht. \& J.Presl (von Berchtold \& Presl 1820) \\ Family Begoniaceae C. Agardh (Agardh 1824) \\ Genus Begonia L. (Linnaeus 1753)
}

\section{Key to the Begonia of Sumatra}

The key covers 58 of the 63 currently accepted names in Begonia for Sumatra. Six names are excluded, of which 5 are those described by Jack (Jack 1822) (B. caespitosa Jack, B. geniculata Jack, B. orbiculata Jack and B. pilosa Jack) for which the type material has been lost and no other specimens are known (Hughes \& Girmansyah 2011b), and one described by Miquel [B. hasskarliana (Miq.)A.DC. (de Candolle 1864; basionym Miquel 1856)] for which no specimens are known. In all cases the original descriptions for those species do not provide enough detail to enable confident placement in the key. Some of the couplets key out to more than one name, as there are several names which appear refer to the same species, although they have not been formally synonymised to date.

1. Plant without an erect main stem, petioles and peduncles arising from a rhizome (§ Reichenheimia)

- $\quad$ Plant with some parts of the stem erect, with at least some internodes $>2 \mathrm{~cm}$ apart ................. 2

2. Plants rhizomatous at the base, erect stem portion repent against tree trunks or rocks, styles 2, fruit 2-locular with one enlarged wing (§ Platycentrum)

- Plants rhizomatous or not at the base, erect stem portion self-supporting, styles 3, fruit 3-locular with equal or subequal wings or wings absent

3. Fruits fleshy berries without wings (ridges sometimes present); anthers with an extended connective, dehiscing through lateral slits (§ Sphenanthera)

- $\quad$ Fruits dry dehiscent, winged; anthers without an extended connective, dehiscing through slits on one face of the anther

4. Plants erect, cane like, stems glabrous, inflorescences cymose, ovaries glabrous (§ Petermannia and cane species unplaced to section).

- $\quad$ Plants spreading, stems hairy, inflorescences fasciculate, ovaries with short hairs (§ Bracteibegonia)

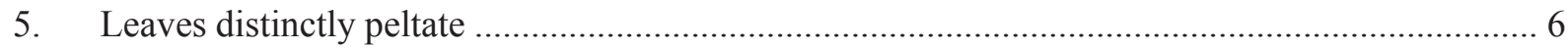

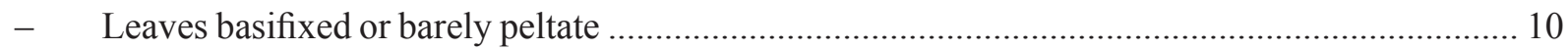

6. Leaves sparsely pilose above ……………....................... B. sudjanae C.-A.Jansson (Jansson 1963)

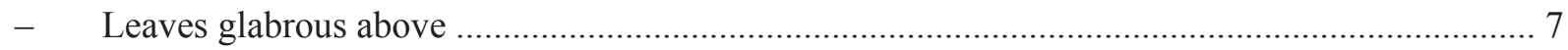

7. Petioles densely pilose .......................................................... B. halabanensis M.Hughes sp. nov.

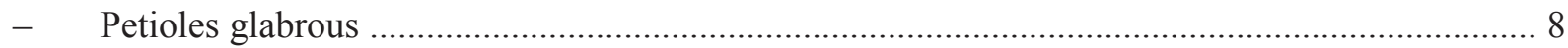

8. Petioles triangular in cross-section, lamina rugose ................ B. goegoensis N.E.Br. (Brown 1882)

- Petioles terete in cross-section, lamina not rugose ….................................................................. 9 
9. Leaves purple in the centre, rhizome creeping, fruits recurved on a stiff pedicel

- $\quad$ Leaves uniform green, rhizome erect, fruits dangling on a thin pedicel B. kudoensis Girm. sp. nov.

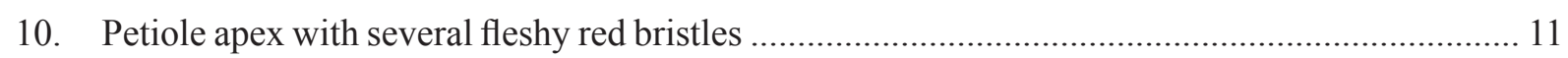

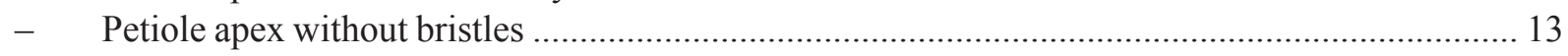

11. Leaves with acute lobes .................................................................................................... 12

- Leaves without lobes ................................................... B. korthalsiana Miq. ex M.Hughes sp. nov.

12. Leaf base cuneate

B. fluvialis M.Hughes sp. nov.

- Leaf base cordate . B. sublobata Jack (Jack 1822)

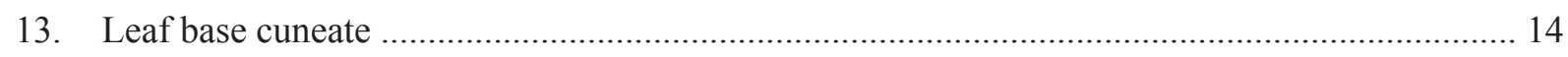

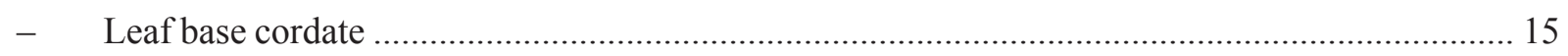

14. Leaf lamina c. $1 \mathrm{~cm}$ wide, subsymmetric

B. lilliputana M.Hughes sp. nov.

- Leaf lamina 1.4-3 cm wide, asymmetric B. inversa Irmsch. (Irmscher 1954)

15. Leaf lamina densely pilose above

B. puspitae Ardi (Hughes et al. 2009)

- Leaf lamina glabrous above 16

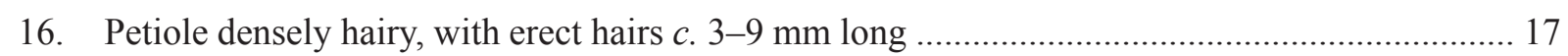

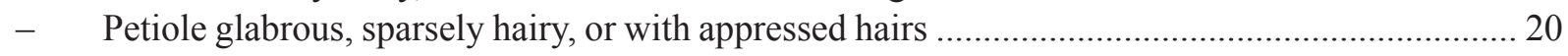

17. Leaf lamina broadly ovate, basal lobes not overlapping ............. B. trichopoda Miq. (Miquel 1856)

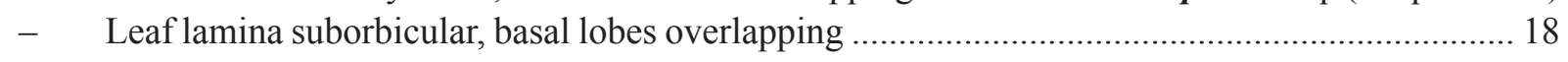

18. Leaf lamina with $3-5$ short acute points ................................. B. kemumuensis M. Hughes sp. nov.

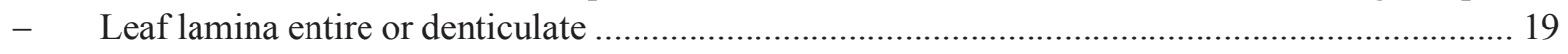

19. Petioles and peduncles 30-60 cm long, inflorescence with $c .100$ flowers

B. sychnantha L.B.Sm. \& Wassh. (Smith \& Wasshausen 1984)

- $\quad$ Petioles and peduncles $<30 \mathrm{~cm}$ long, inflorescence with $c .50$ flowers

B. raoensis M.Hughes sp. nov.

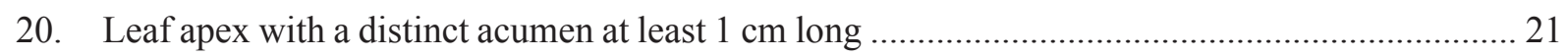

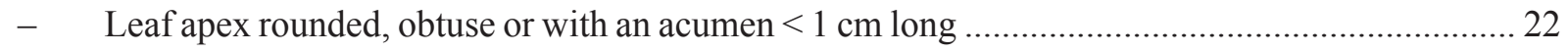

21. Leaf lamina with $3-5$ short acute points

- Leaf lamina entire or denticulate

B. longipedunculata Golding \& Kareg. (Smith \& Wasshausen 1984)

B. stictopoda (Miq.) A.DC. (de Candolle 1864; basionym Miquel 1856)

22. Tepals on male flowers with bristles at the base

B. pasamanensis M.Hughes (Hughes et al. 2009)

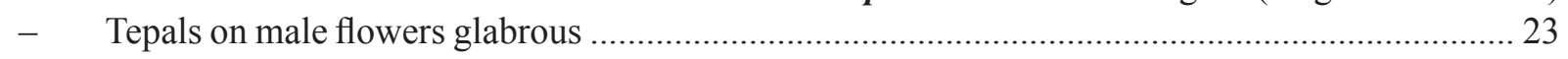

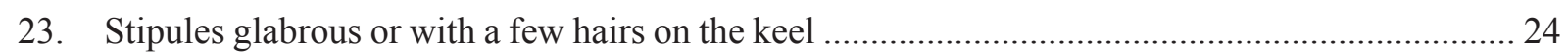

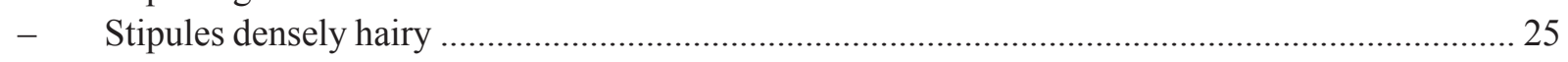


24. Leaf lamina suborbicular, $>6 \mathrm{~cm}$ in diameter

B. rajah Ridl. (Ridley 1894)

- Leaf lamina ovate, $<4.5 \mathrm{~cm}$ long B. ionophylla Irmsch. (Irmscher 1913)

25. Leaf lamina ovate

B. droopiae Ardi (Ardi \& Hughes 2010)

Leaf lamina suborbicular 26

26. Leaf lamina 5-9.5 $\times 4-8 \mathrm{~cm}$, glossy green above

B. simolapensis Ardi sp. nov. Leaf lamina $2.7-4.5 \times 2.6-3.7 \mathrm{~cm}$, matt olive green above B. olivacea Ardi sp. nov.

27. Leaves hairy above 28

Leaves glabrous above

28. Leaf lamina not variegated, with acute lobes, with bristly hairs

B. areolata Miq. (Miquel 1855) / B. beccariana Ridl. (Ridley 1923) / B. bifolia Ridl. (Ridley 1917)

- Leaf lamina variegated, not lobed, with soft hairs

B. tuberculosa Girm. (Hughes et al. 2009)

29. Leaf lamina lobed, female flowers with 6 tepals

B. leuserensis M.Hughes sp. nov.

- Leaf lamina not lobed, female flowers with 5 tepals

B. altissima Ridl. (Ridley 1917) / B. laevis Ridl. (Ridley 1917) / B. teysmanniana (Miq.) Tebbitt (Tebbitt \& Dickson 2000; basionym Miquel 1856)

30. Leaf lamina with $5-7$ broad pointed lobes

B. multangula Blume (Blume 1827)

- Leaf lamina not lobed

31. Leaf lamina ovate

- Leaf lamina lanceolate

B. longifolia Blume (Blume 1827)

32. Plant with white hairs, fruits borne apically in pairs

B. scottii Tebbitt (Tebbitt 2005)

- Plant with pink hairs, fruits borne basally in a cluster of 10-20

B. pseudoscottii Girm. sp. nov.

33. Leaf lamina with acute lobes

B. laruei M.Hughes (Hughes et al. 2009)

- Leaf lamina without lobes

34. Petioles tuberculose-tomentose

B. padangensis Irmsch. (Irmscher 1954)

Petioles glabrous

35. Leaf lamina with rows of bristles between the veins on the upper surface.......

B. vuijckii Koord. (Koorders 1912) / B. tenericaulis Ridl. (Ridley 1925)

- Leaf lamina glabrous above

36. Inflorescences arising at the base of a shortened petiole, appearing to have a subtending leaf, female flowers distal

- Inflorescences without a subtending leaf on a shortened petiole, female flowers basal

37. Leaf margin dentate-denticulate, flowers white, $1300-1800(-2300)$ metres altitude

B. divaricata Irmsch. (Irmscher 1954)

- Leaf margin denticulate, flowers pink, 30-600(-1200) metres altitude

B. gracilicyma Irmsch. ex M.Hughes (Hughes et al. 2009)

38. Lamina elongate-lanceolate, apex long acuminate, margin entire to shallowly undulate

B. harauensis Girm. sp. nov. 
- lamina ovate or lanceolate, apex acuminate or shortly acuminate, margin dentate to shallowly

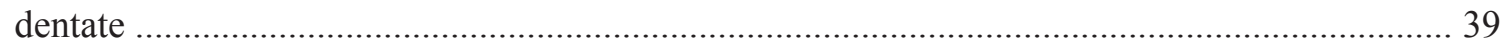

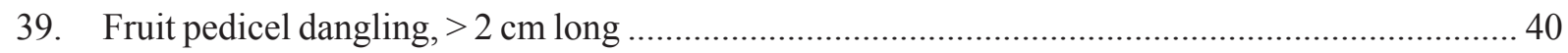

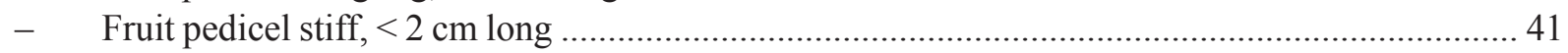

40. Fruit bell-shaped, leaves $6-15 \mathrm{~cm}$ wide

B. atricha Miq. (A.DC.) (de Candolle 1864; basionym Miquel 1856)

- $\quad$ Fruit suborbicular, leaves $<6 \mathrm{~cm}$ wide ......................................... B. repanda Blume (Blume 1827)

41. Fruits borne in clusters of up to 5 pairs, fruit wings $<3 \mathrm{~mm}$ wide

B. multijugata M.Hughes (Hughes et al. 2009)

- $\quad$ Fruits borne singly or in pairs, fruit wings $>3 \mathrm{~mm}$ wide

42. Locule distinctly long and narrow, c. $4 \times 0.5 \mathrm{~cm}$........ B. dolichocarpa Girm. (Girmansyah 2012)

- $\quad$ Locule not distinctly long and narrow, less than $2 \mathrm{~cm}$ long

43. Male flowers with 4 tepals, female flowers with 5 tepals, leaves ovate

B. holttumii Irmsch. (Irmscher 1913)

- Male flowers with 2 tepals, female flowers with 3 tepals, leaves oblong-lanceolate

B. racemosa Jack (Jack 1822)

44. Stipules broadly ovate, leafy, staying green near the apex of the plant

- Stipules lanceolate, rapidly drying papery

45. Leaves sinuate

B. aberrans Irmsch. (Irmscher 1954)

- Leaves sinuate-dentate B. horsfieldii Miq. ex A.DC. (de Candolle 1864)

46. Leaves dentate-denticulate, margin hairy 47

- $\quad$ Leaves entire to sinuate-dentate, margin glabrous 48

47. Leaves c. $8 \times 4 \mathrm{~cm}$, with dense soft white hairs above B. bracteata Jack (Jack 1822) Leaves $2.5-5.5 \times 1.2-2.5 \mathrm{~cm}$, with evenly spaced bristles above between the veins

B. jackiana M.Hughes sp. nov.

48. Plants less than $20 \mathrm{~cm}$ tall, becoming repent and rooting at the lower nodes, often with less than 5 leaves

- Plants taller than $20 \mathrm{~cm}$, not repent, usually with more than 5 leaves .....

49. Leaves ovate, margin entire

B. triginticollium Girm. (Girmansyah 2012)

- Leaves ovate-oblong, margin sinuate-dentate or dentate-crenate

50. Male flowers with 2 tepals, stem, petioles and leaf underside with bright red hairs

B. beludruvenea M.Hughes sp. nov.

- Male flowers with 4 tepals, stem, petioles and leaf underside with white hairs B. verecunda M.Hughes (Hughes et al. 2009)

51. Leaf lamina ovate-laceolate, base subcordate, fruit cuneate at base, male flowers with 4 tepals ....... B. lepidella Ridl. (Ridley 1917)

- Leaf lamina elongate-lanceolate, base narrowly cuneate, fruit rounded at base, male flowers with 2 tepals B. flexula Ridl. (Ridley 1923) 
Begonia beludruvenea M.Hughes sp. nov. § Bracteibegonia

urn:lsid:ipni.org:names:77151638-1

Figs 1,2

\section{Diagnosis}

The velvety red hairs on the stem and veins are distinctive. B. beludruvenea is nearest to $B$. verecunda M.Hughes (Hughes et al. 2009) from Gunung Leuser National Park in terms of its habit and leaf shape, but the hairs are denser and fleshier, the male flowers are slightly larger (10-14 mm diameter, not c. $9 \mathrm{~mm}$ ) and have 2 (not 4) tepals, and the styles are longer in the female flowers (c. $5 \mathrm{~mm}$, not 3-4 mm). $B$. verecunda has not been recorded from limestone, whereas $B$. beludruvenea is a limestone endemic.

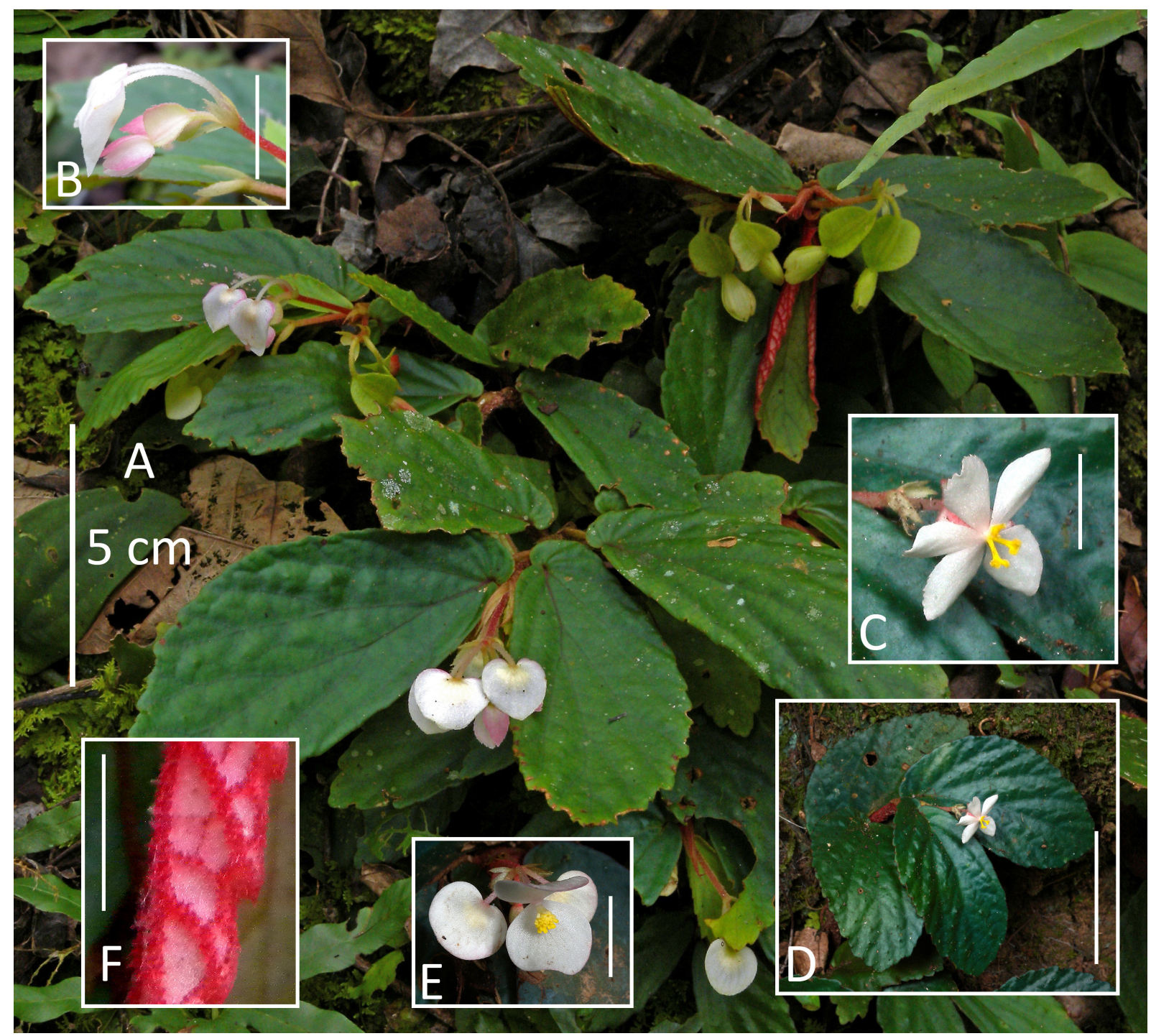

Fig 1. Begonia beludruvenea M.Hughes sp. nov. A. Habit. B. Inflorescence with two male flower buds and two female buds beneath. C. Female flower. D. Habit showing blue iridescence. E. Male flower. F. Underside of leaf margin showing red hairs. C-E from Bukit Sebelah, Hughes \& Taufiq MH1549A; A, B, F from Bukit Sebelah, Hughes \& Taufiq MH1541. Scale bars on insets: B, C, E, F =1 cm; D = $5 \mathrm{~cm}$. 


\section{Etymology}

The epithet is derived from the Indonesian word for "velvet", beludru, referring to the dense red hairs on the veins.

\section{Type}

SUMATRA: West Sumatra, Bukit Sebelah, 400 m, 22 Jul. 2009, Hughes \& Taufiq MH1541 (holo-: BO; iso-: E).

\section{Additional material}

SUMATRA: West Sumatra, Bukit Sebelah, 350 m, 20 May 1983, Pannell 1860 (BO); ibid., 450 m, 23 Jul. 2009, Hughes \& Taufiq MH1549A (BO, E).

\section{Description}

Erect low-growing caulescent herb c. $15 \mathrm{~cm}$ tall; stem strigose with red fleshy hairs, internodes $1-2 \mathrm{~cm}$ long. Stipules persistent, hairy at the base, c. $10 \mathrm{~mm}$ long, elongate lanceolate, apex ending in a fine hair. Leaves: petiole $4-15 \mathrm{~mm}$ long, terete, red strigose; lamina obovate-oblong to elliptic, asymmetric, 6-9 $\times 2-4.5 \mathrm{~cm}$, basifixed, base cordate, oblique, lobes overlapping slightly, larger lobe auriculate; upper surface dark green, sometimes with a blue iridescence, glabrous or with sparse evenly spaced bristles between the veins; underside paler green, red strigose on the veins; venation pinnate-palmate; margin dentate-crenate, apex obtuse to acute. Inflorescence terminal, total length $c .5 \mathrm{~cm}$, a compressed cyme, appearing fasciculate, protandrous, with $c$. 4 flowers, 2 male and 2 female; primary peduncle $1.5-2.5 \mathrm{~cm}$, with short white hairs; bracts persistent, lanceolate, 2-7 mm long, margin denticulate, apex acute. Male flower: pedicel c. $15 \mathrm{~mm}$ long, white, with short white hairs; tepals 2, sub-orbicular, based cordate when young, truncate when open, white, $10 \times 12-14 \mathrm{~mm}$, minutely denticulate to entire, sparsely puberulous on the veins, apex rounded or obtuse; androecium yellow, symmetric, a loose fascicle, slightly asymmetric, shorter stamens uppermost; stamens 25-30, filaments fused at the base into a short column, unequal, 1.5-2 mm; anthers oblong, subequal, 1.5-2 mm, hooded, apex retuse, dehiscing through slits about $2 / 3$ the length of the anther. Female flower: pedicel 5-9 mm long, pale green, sparsely hairy; ovary pinkishwhite, hairy on the capsule and wing edge, triangular, total size $10 \times 8 \mathrm{~mm}$ including the wings; capsule ellipsoid, $9 \times 2-3 \mathrm{~mm}$, 3-locular, placentae entire; wings subequal, 2-3 mm wide; tepals 5, obovateelliptic, pale pink in bud, white when open, 7-10 mm long, outer 3 denticulate, sparsely puberulent, $5 \mathrm{~mm}$ wide, inner 2 entire, glabrous, $4 \mathrm{~mm}$ wide, tepals closing and turning green after pollination and during fruit maturation; stigmas 3 , free, Y-shaped, stigmatic surface once spirally twisted. Fruit recurved on a stiff pedicel c. $10 \mathrm{~mm}$ long, total size $13 \times 10 \mathrm{~mm}$ including the wings, larger wing $13 \times 3 \mathrm{~mm}$ and more rounded at the base than the 2 smaller ones, 2 smaller wings $10 \times 3 \mathrm{~mm}$; apex truncate.

\section{Distribution and habitat}

Endemic to the Bukit Sebelah limestone in West Sumatra (Fig. 2), where it grows on steep, shaded clay soil banks over the limestone base rock.

\section{Conservation status}

The bulk of the distribution lies within the Bukit Sebelah and Batang Pangean protection forest which is likely to represent its full natural range. Although there is low level disturbance around the forest tracks, the reserve is reasonably intact and populations of $B$. beludruvenea can colonise previously disturbed bare soil banks. Although naturally rare, following IUCN (2012) we consider the species as Least Concern as long as the reserve is well managed. 
Begonia fluvialis M.Hughes sp. nov. § Reichenheimia urn:Isid:ipni.org:names:77151639-1

Figs 3,4

\section{Diagnosis}

A rheophytically adapted sister species closely allied to B. sublobata Jack (Jack 1822), from which it differs in its smaller size $(<20 \mathrm{~cm}$ high, not $20-30 \mathrm{~cm}$ high $)$ and its smaller, narrower leaves $(8-15 \times$

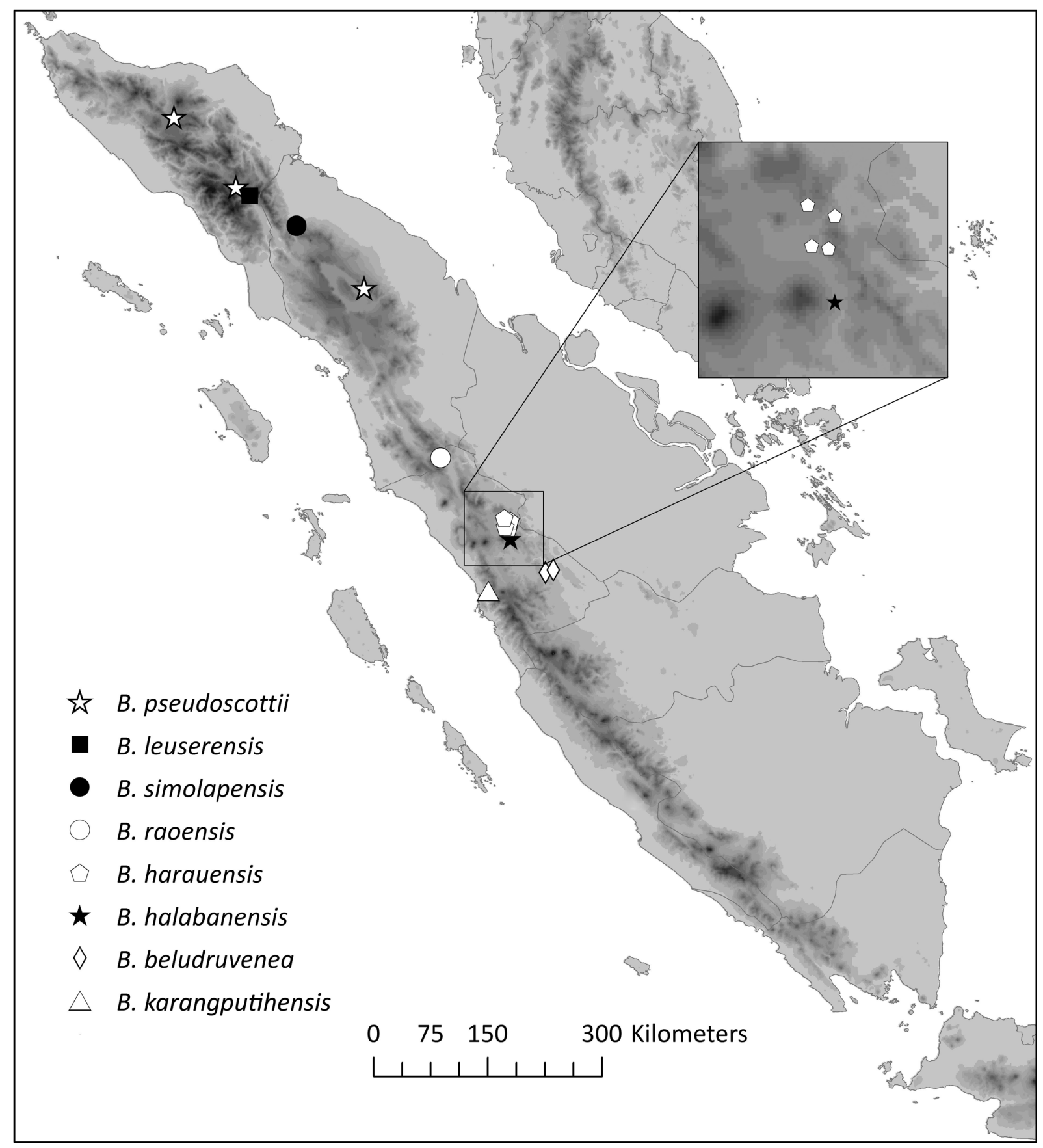

Fig. 2. Map of Sumatra showing the full known species distributions based on collection localities. Each point may represent more than one collection. 
$1.5-5.5 \mathrm{~cm}$, not $c .12 \times 12 \mathrm{~cm}$ ). Other distinctive characters are the petioles being triangular in cross section, and the cuneate lamina with up to 3 apical lobes. See also the diagnosis for $B$. lilliputana below for a comparison with that species.

\section{Etymology}

The epithet is derived from the Latin fluvius (river) and means "of the river".

\section{Type}

SUMATRA: West Sumatra, Sungai Pinang, Batang Ayer Manjuto, 350 m, 12 Aug. 2010, Girmansyah, Hughes \& Nurainas DEDEN1489 (holo-: BO; iso-: E).

\section{Additional material}

SUMATRA: West Sumatra, Sungai Pinang, Batang Ayer Manjuto, 350 m, 12 Aug. 2010, Girmansyah, Hughes \& Nurainas DEDEN1490 (BO, E).

\section{Description}

Repent acaulescent lithophytic riverine herb, $10-20 \mathrm{~cm}$ tall; stem rhizomatous, internodes $c .0 .5 \mathrm{~cm}$ long. Stipules persistent, with a few stiff hairs on the keel or glabrous, $10 \mathrm{~mm}$ long, lanceolate, with

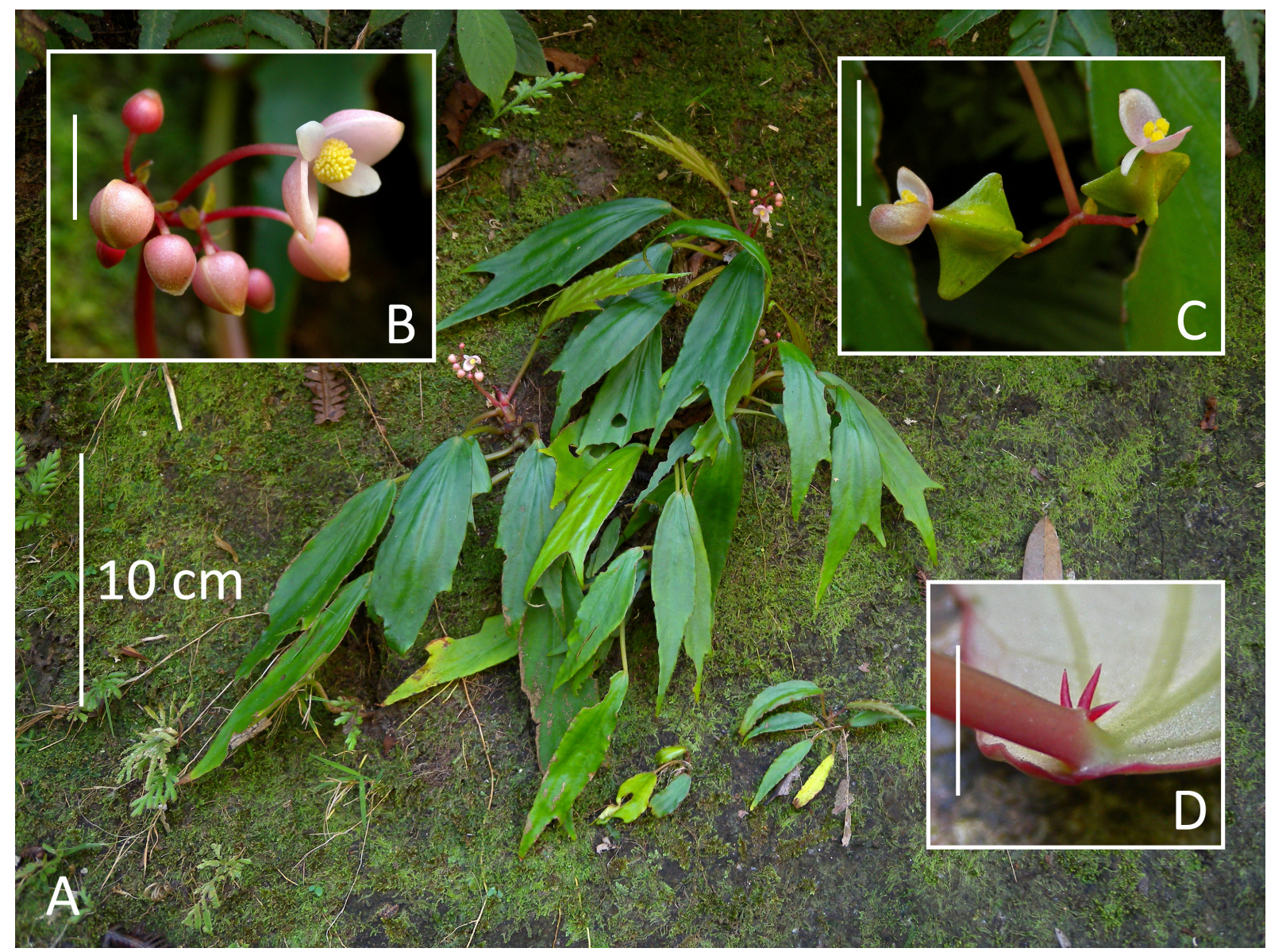

Fig. 3. Begonia fluvialis M.Hughes sp. nov. A. Habit. B. Inflorescence in male phase. C. Two female flowers. D. Petiole apex showing three red bristles. All photographs from Batang Ayer Manjuto of the type Girmansyah et al. DEDEN1489. Scale bars on insets $=1 \mathrm{~cm}$. 
a filiform extension at the apex. Leaves: petiole 6-10 cm long, triangular in cross section, with sparse minute glandular hairs when young rapidly becoming glabrous with age, with a semicircle of 3-6 stiff red bristles at the apex, bristles 2-4 mm long; lamina, cuneate with 1-3 apical triangular lobes, symmetric, $8-15 \times 1.5-5.5 \mathrm{~cm}$, basifixed, base minutely cordate and slightly auriculate, upper surface light green, glabrous on both sides, venation palmate-pinnate; margin sub entire to shallowly dentate, with recurved stiff teeth at the end of the veins, apex acuminate. Inflorescences axillary, total length 15-18 cm, cymose, branching 3-4 times, 12-15 flowered, bisexual, protandrous; primary peduncle 13-16 cm; bracts caducous, sub-orbicular, 2-3 mm long, margin entire. Male flowers: pedicel red, c. $8 \mathrm{~mm}$ long, glabrous; tepals 4 ; outer tepals broad ovate to sub orbicular, fleshy, 6-7 $\times 5-6 \mathrm{~mm}$, pale

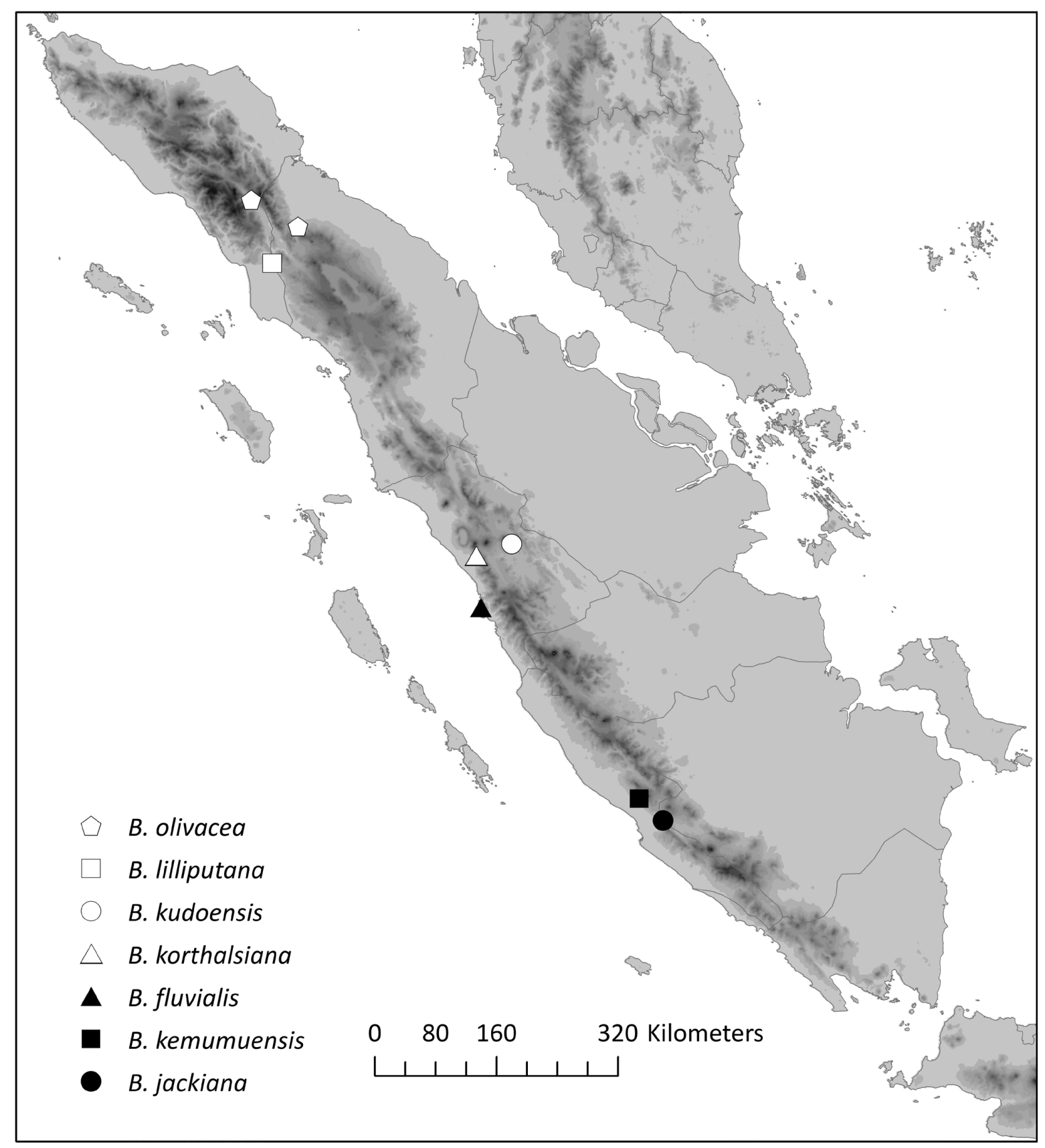

Fig. 4. Map of Sumatra showing the full known species distributions based on collection localities. Each point may represent more than one collection. 
pink, glabrous, margin with a distinct rim; inner tepals elliptic, $4 \times 2 \mathrm{~mm}$, white; androecium pale yellow, globose; stamens $c$. 80; filaments, subequal, $0.5 \mathrm{~mm}$ long, fused at the base into a $0.5 \mathrm{~mm}$ long column; anther about as long as the filament, elliptic-obtriangular, $0.5 \mathrm{~mm}$ long, connective slightly retuse, dehiscing through slits about half the length of the anther, slits placed laterally. Female flowers: pedicel c. $5 \mathrm{~mm}$ long; ovary green, glabrous, $5 \times 12 \mathrm{~mm}$ including the wings; capsule orbicular, $4 \mathrm{~mm}$ in diameter, 3 locular, placentae entire; wings triangular, c. $4 \mathrm{~mm}$ long; tepals 2-3; outer tepals 2, same as male flower; inner tepal 0-1, same as male flower; stigmas 3, shallowly Y-shaped, surface tightly twice spirally twisted, greenish yellow. Fruit recurved on a 8-12 mm long pedicel; rounded at base; capsule orbicular, 5-6 $\mathrm{mm}$ in diameter; total size $8 \times 15 \mathrm{~mm}$ including the wings; wings equal to subequal, $5 \times$ $7 \mathrm{~mm}$, apex obtuse.

\section{Distribution and habitat}

Only known from two collections from neighbouring streams near Sungai Pinang in West Sumatra (Fig. 4). B. fluvialis grows on moss covered rocks at the side of and emerging from streams running down the mountainside.

\section{Conservation status}

The forest habitat of the type locality seems to be well managed and under some community protection. However the lack of a formally gazetted protected area and the potential for landslides to encroach the streamside habitat means $B$. fluvialis should be considered Vulnerable under criterion VUD2 of IUCN (2012).

\section{Begonia halabanensis M.Hughes sp. nov. § Reichenheimia urn:lsid:ipni.org:names:77151640-1}

Figs 2, 5

\section{Diagnosis}

The peltate and succulent leaves are also found in B. kudoensis, however B. halabanensis has a thickly hairy rhizome and petioles (not glabrous), male flowers with 2 tepals (not 4), larger inflorescences (with c. 80 flowers, not c. 40) and fruit with a truncate (not obtuse) apex. The key from couplet 6 onwards deals with all 5 currently described peltate species from Sumatra.

\section{Etymology}

The epithet refers to the distribution of the species in Halaban in West Sumatra near Payakumbuh.

\section{Type}

SUMATRA: West Sumatra, Pajakumbuh, Halaban, 800 m, 29 Jan. 1950, Meijer 7550 (holo-: L).

\section{Description}

Erect acaulescent herb 20-30 cm tall; stem rhizomatous, stout, internodes $c .1 \mathrm{~cm}$ long, densely covered in a matted indumentum of reddish brown multi-branched thick hairs $c .1 \mathrm{~cm}$ long. Stipules lanceolate, stout, $2-3 \times 1.5 \mathrm{~cm}$, fibrous, persistent, with thick, long hairs. Leaves: petiole $c .20 \mathrm{~cm}$ long, cross section unknown, with quite dense $5 \mathrm{~mm}$ long hairs; lamina peltate, point of petiole attachment placed to within $3 \mathrm{~cm}$ of the margin, suborbicular, 10-15 $\times 10-15 \mathrm{~cm}$, thick and succulent, base rounded, margin entire in outline, with evenly spaced $2 \mathrm{~mm}$ long stiff rounded teeth that are recurved underneath, margin also with a fringe of $5 \mathrm{~mm}$ long hairs, apex acute, underside with many pale dots of stomatal clusters, venation palmate, main veins 8 , quite widely spaced over most of the lamina. Inflorescences axillary, c. $40 \mathrm{~cm}$ long and exceeding the leaves, cymose, many-flowered, branching c. 8 times, bisexual, protandrous; bracts elliptic, minute, glabrous, entire, c. $2 \times 1.5 \mathrm{~mm}$ towards the terminal branches, basal pair not seen. 
Male flowers: pedicel $5 \mathrm{~mm}$ long, slender, glabrous; tepals 2, orbicular, entire, glabrous, c. $8 \times 8 \mathrm{~mm}$; androecium globose, symmetric, with $c$. 40 stamens, filaments unequal, fused at base, shorter to slightly longer than the anther, anther $0.75 \mathrm{~mm}$ long, ellipsoid-obtriangular, dehiscing through short slits near the apex, apex retuse, not hooded. Female flowers unknown. Fruits pendent on a 15-20 mm long hair-like pedicel, borne in a cyme of $c$. 50, total size $9 \times 21 \mathrm{~mm}$; capsule globose, $6 \mathrm{~mm}$ in diameter, three-locular, placentae entire; wings 3 , subequal, $8-10 \times 8-9 \mathrm{~mm}$, tips rounded; apex obtuse.

\section{Distribution and habitat}

Found on limestone, endemic to the type locality in Halaban, West Sumatra (Fig. 2). The thick fleshy leaves and densely hairy rhizome of this very distinctive species imply adaptation to dryer habitats. Known only from the type.

\section{Conservation status}

The distribution of limestone habitat in the Halaban area is not very well known, and the exact location of the type collection is not clear. Whether the species is already extinct, or in fact thriving in a naturally small population needs further fieldwork in the Halaban region; we assess B. halabanensis to be Data Deficient (IUCN 2012).

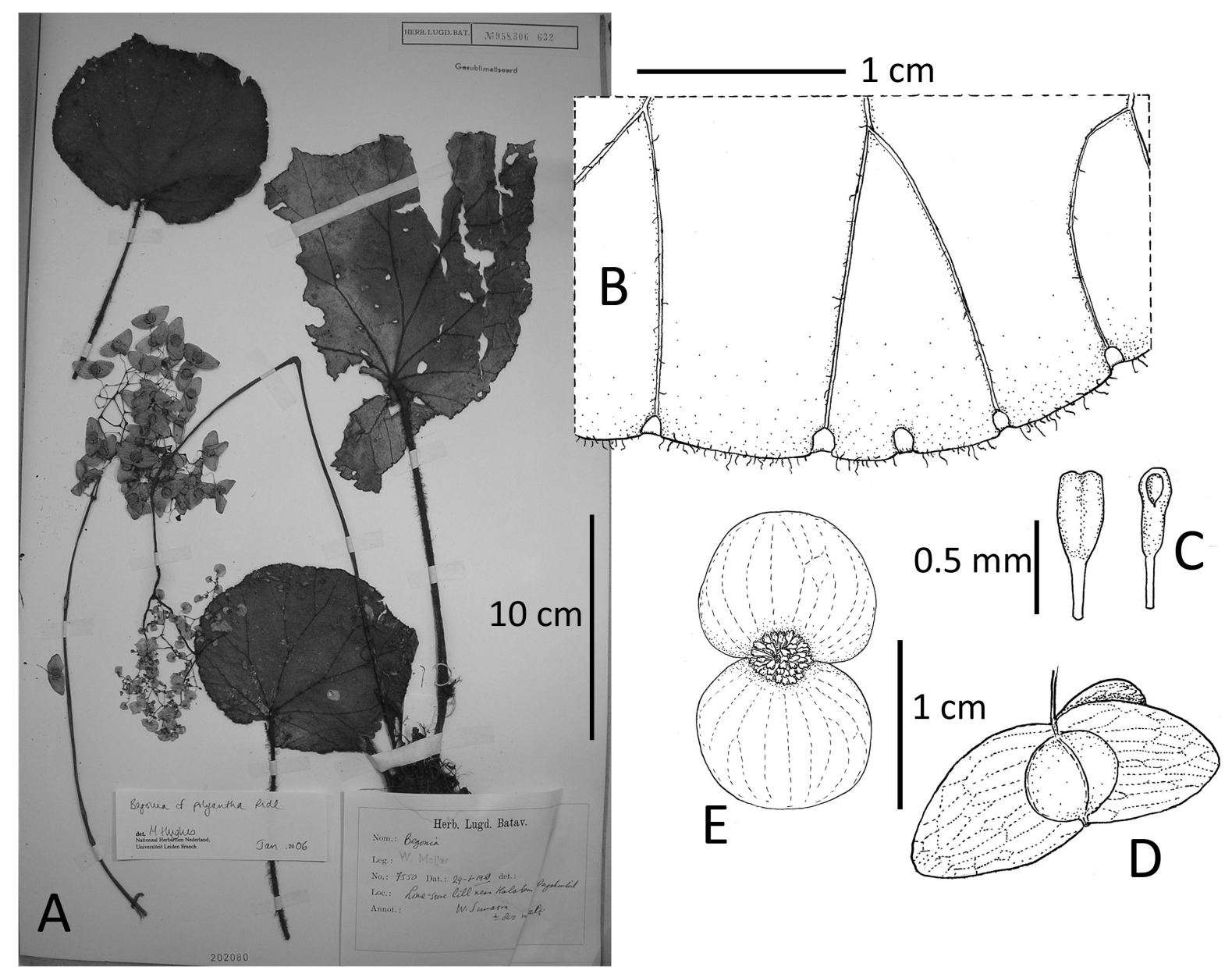

Fig. 5. Begonia halabanensis M.Hughes sp. nov. A. Holotype [Meijer 7550 (L)]. B. Portion of leaf lamina underside showing margin hairs and recurved teeth. C. Anthers. D. Fruit. E. Male flower. Drawings by M. Hughes. 


\title{
Begonia harauensis Girm. sp. nov. § Petermannia \\ urn:Isid:ipni.org:names:77151641-1
}

\author{
Figs 2, 6
}

\section{Diagnosis}

The inflorescence and habit of $B$. harauensis most closely resembles that of $B$. laruei M.Hughes (Hughes et al. 2009) from North Sumatra and Aceh, but it is a smaller species (c. $50 \mathrm{~cm}$ tall, not to $c .100 \mathrm{~cm}$ tall) with narrower leaves $(2-5.5 \mathrm{~cm}$ wide, not $3.5-10 \mathrm{~cm}$ wide) without lobes, which are so asymmetric as to almost displace the point of petiole attachment to the side of the leaf. The shrinkage that occurs upon drying accentuates this, giving the leaves a tear-drop shape.

\section{Etymology}

The epithet refers to the distribution of the species, Lembah Harau in West Sumatra near Payakumbuh.

\section{Type}

SUMATRA: West Sumatra, Lembah Harau Nature Reserve, 500 m, 24 Jul. 2009, Hughes \& Rubite MH 1557 (holo-: BO; iso-: E).

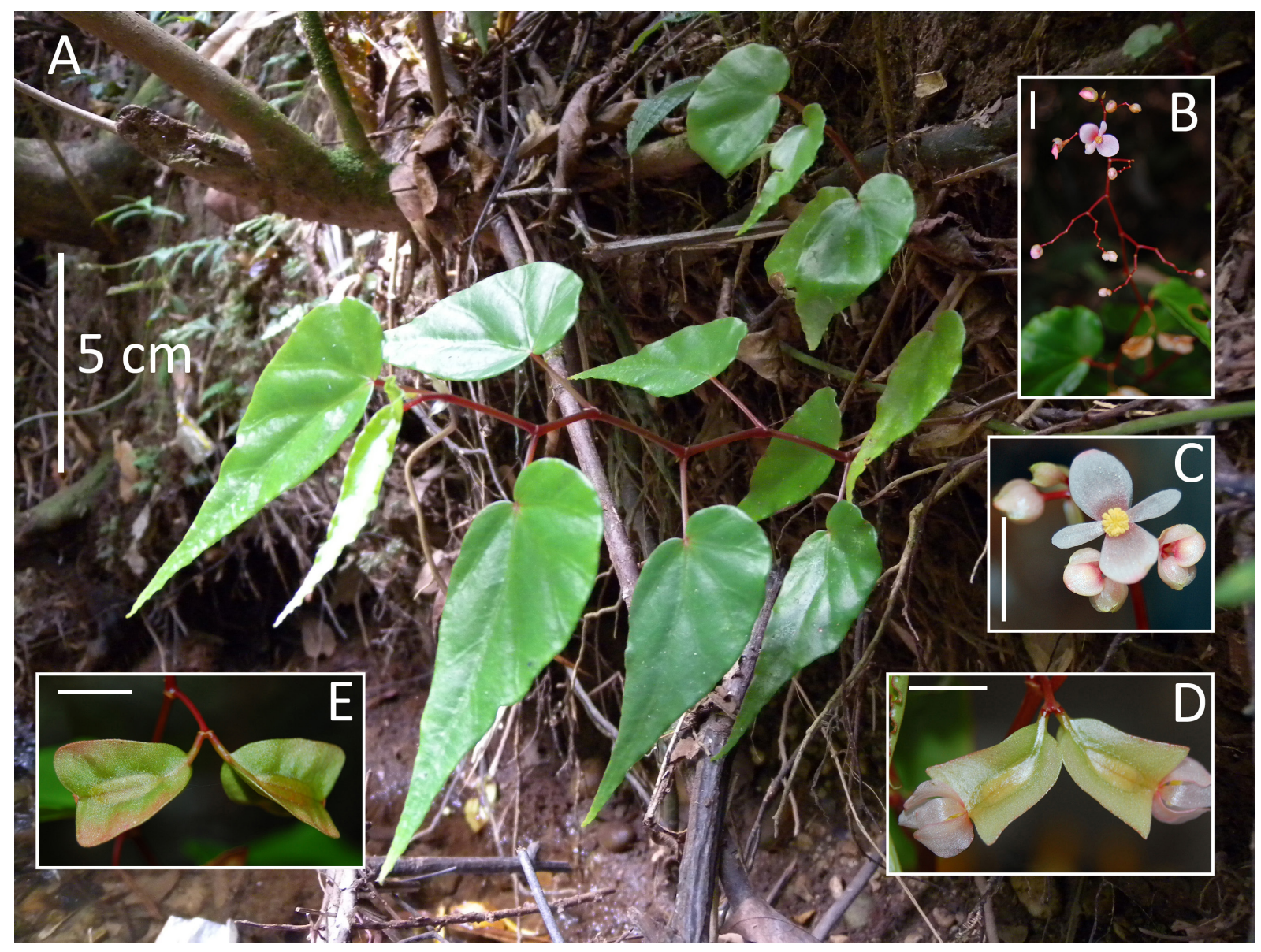

Fig. 6. Begonia harauensis Girm. sp. nov. A. Habit (Lembah Harau Nature Reserve, Hughes, M. \& Taufiq, A. MH 1556). B. Male inflorescence. C. Male flower. D. Pair of female flowers showing ovary. E. Unripe fruit. Insets from plant cultivated in Bogor Botanical Garden (accession number B200608257/ JS 436, derived from material collected in Lembah Harau). Scale bars on insets $=1 \mathrm{~cm}$. 


\section{Additional material}

SUMATRA: West Sumatra, Kepala Banda, ANDA collectors 4 (ANDA); ibid., 22 Oct. 1989, ANDA collectors 106 (ANDA); ibid., 22 Oct. 1989, ANDA collectors 142 (ANDA); ibid., 3 Apr. 1988, Darmansyah 33 (ANDA); ibid., 10 Apr. 1988, Lani \& Arnov 48 (ANDA); ibid., 10 Nov. 1984, Meriyatmi, E. 12 (ANDA); ibid., 3 Apr. 1988, Ranti 12 (ANDA); ibid., 3 Apr. 1988, Suluh, B. 41 (ANDA); Lembah Harau Nature Reserve, 3 Apr. 1988, Heravela 22 (ANDA); ibid., 27 Aug. 1983, Hotta, M. \& et. al. 335 (ANDA); ibid., 24 Jul. 2009, Hughes, M. \& Rubite, R. MH1557 (E); ibid., 23 Jul. 2009, Hughes, M. \& Taufiq, A. MH1556 (E); Lembah Harau Nature Reserve, Sarasah Bonta, 14 Nov. 1992, ANDA collectors 9 (ANDA); ibid., 27 Aug. 1983, ANDA collectors 4R (ANDA); ibid., 2 Apr. 1988, ANDA collectors 11 (ANDA); ibid., 2 Mar. 2001, ANDA collectors 29 (ANDA); ibid., 14 Nov. 1992, ANDA collectors 49 (ANDA); ibid., Dec. 1994, ANDA collectors 51 (ANDA); ibid., 15 Nov. 1992, ANDA collectors 63 (ANDA); ibid., 10 Dec. 1994, ANDA collectors 67 (ANDA); ibid., 11 Dec. 1994, ANDA collectors 92 (ANDA); ibid., 11 Dec. 1994, ANDA collectors 95 (ANDA); ibid., 11 Dec. 1994, ANDA collectors 99 (ANDA); ibid., 10 Dec. 1984, ANDA collectors 156 (ANDA); ibid., 11 Dec. 1994, Fit, Nung, Eci, Tis \& Martin 78 (ANDA); ibid., 10 Dec. 1994, Irya, Eva, Del, Titin \& Yenny 48 (ANDA); ibid., 27 Aug. 1983, Nelly, Delli, Harry \& Eka 83 (ANDA); ibid., 10 Dec. 1994, On, Fera, Yat, Tin \& Rina, S. 3 (ANDA); ibid., 11 Dec. 1994, Pions, Eka, Wasti, Dewi \& Len 68 (ANDA); West Sumatra, Pajakumbuh, Taram, 3 Apr. 1988, Johanes, R. 23 (ANDA); ibid., 23 Aug. 1956, Meijer, W. 6843 (L); River Tjampo, Aug. 1957, Ismail $47(\mathrm{~L})$.

\section{Description}

Erect caulescent herb to $c$. $50 \mathrm{~cm}$ tall; stem erect, glabrous, red, internodes $2-8 \mathrm{~cm}$ long. Stipules deciduous, glabrous, lanceolate, $8 \times 4 \mathrm{~mm}$, apex acute. Leaves: petiole $1.5-4 \mathrm{~cm}$, terete, minutely puberulent; lamina lanceolate, glabrous, strongly asymmetric, basifixed, base shallowly cordate to sub truncate, apex long acuminate, $8-16 \times 2-5.5 \mathrm{~cm}$, uniform pale green, midrib 7-13 cm, venation palmatepinnate, margin subentire to sparsely denticulate. Inflorescences terminal, up to $22 \mathrm{~cm}$ in total length, a raceme of cymes, glabrous, with 2-4 female flowers at the base, up to $c$. 50 male flowers distally, protogynous; primary peduncle $3-7 \mathrm{~cm}$ long; bracts deciduous, elliptic, glabrous, entire, $c .7 \times 5 \mathrm{~mm}$, apex rounded. Male flowers: pedicel c. $5 \mathrm{~mm}$ long, glabrous; tepals 4, pale pink, outer 2 tepals orbicular, c. $7 \times 6 \mathrm{~mm}$, glabrous or minutely puberulent adaxially, inner 2 elliptic obovate, $c .5 \times 3 \mathrm{~mm}$; androecium pale yellow, symmetric, globose, stamens $c .35$, filaments subequal, c. $0.5 \mathrm{~mm}$ long, arranged on a short $0.5 \mathrm{~mm}$ long column, anthers oblong, c. $0.5 \mathrm{~mm}$, apex retuse, hooded, dehiscing through slits about half the length of the anther, slits placed laterally. Female flowers: pedicel $2-5 \mathrm{~mm}$ long, glabrous; ovary green, glabrous, total size including wings $17 \times 14$; capsule ellipsoid, 3-locular, placentae bifid; wings three, equal, $15 \times 4 \mathrm{~mm}$; tepals 5, pale pink, outer 2 ovate, $c .7 \times 5 \mathrm{~mm}$, inner 3 elliptic, smaller, $c .7 \times$ $4 \mathrm{~mm}$; styles 3, yellow, c. $4 \mathrm{~mm}$ long, bifid, U-shaped, stigmatic band once spirally twisted. Fruit usually in pairs, on a stiff $5 \mathrm{~mm}$ long pedicel, total size $17 \times 15 \mathrm{~mm}$; apex truncate.

\section{Distribution and habitat}

Endemic to Lembah Harau and immediate surroundings (Fig. 2), where it grows on stream banks and at the base of sandstone cliffs.

\section{Conservation status}

Begonia harauensis is assessed as Least Concern due to its distribution overlapping the Lembah Harau Protection Forest, and the large number of specimens in ANDA giving an indication of a quite common, if locally endemic, plant. 
Begonia jackiana M.Hughes sp. nov. § Bracteibegonia

urn:Isid:ipni.org:names:77151642-1

Figs 4,7

\section{Diagnosis}

Begonia jackiana is unique amongst Sumatran members of sect. Bracteibegonia in its small leaf size $(2.5-5.5 \times 1.2-2.5 \mathrm{~cm})$ and bristles on the upper leaf surface. Its shares a dentate-denticulate hairy leaf margin with $B$. bracteata Jack, which differs in being densely softly pilose above.

\section{Etymology}

The epithet commemorates the Scottish botanist William Jack [1795-1822], as this species was found whilst following in Jack's footsteps in Bengkulu Province (Hughes \& Girmansyah 2011a).

\section{Type}

SUMATRA: Bengkulu, Kapahiang, 680 m, 14 Aug. 2010, Girmansyah \& Hughes DEDEN1494 (holo-: $\mathrm{BO}$, iso-: $\underline{\mathrm{E}}$.

\section{Additional material}

SUMATRA: Bengkulu, Kapahiang, 680 m, 14 Aug. 2010, Girmansyah \& Hughes 1493 (BO, E).

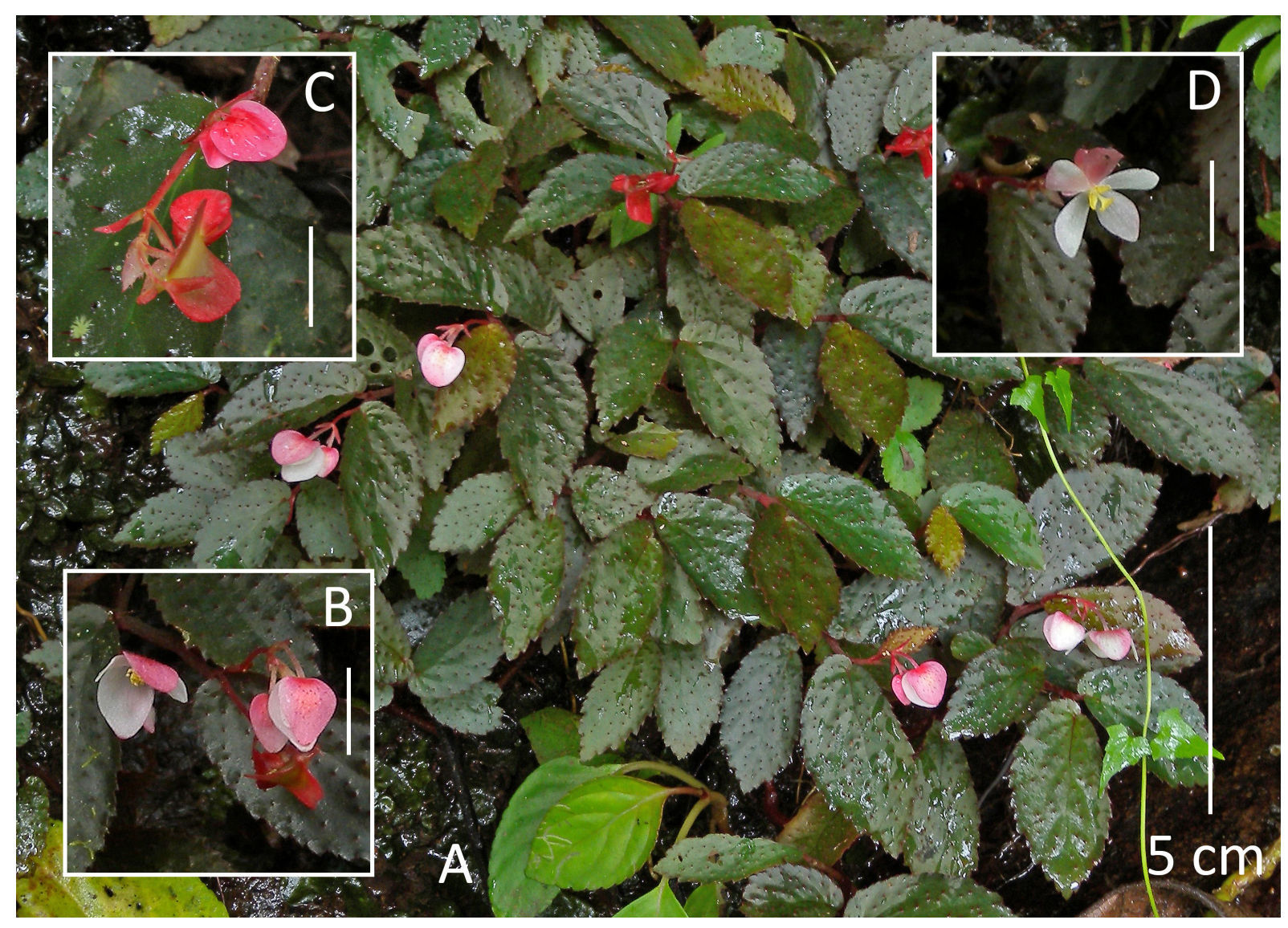

Fig. 7. Begonia jackiana M.Hughes sp. nov. A. Habit. B. Male flowers. C. Inflorescence with female flower recurved after pollination. D. Female flower. All photographs from Kapahiang, of the type Girmansyah \& Hughes DEDEN1494. Scale bars on insets $=1 \mathrm{~cm}$. 


\section{Description}

Small colony forming caulescent erect terrestrial herb, 15-20 cm tall; stem erect, rooting at the lower nodes, densely hairy, internodes $1-3.5 \mathrm{~cm}$ long. Stipules semi-persistent, with sparse hairs on the keel and margin, narrowly lanceolate, $4 \times 1-2 \mathrm{~mm}$. Leaves: petiole $0.4-1 \mathrm{~cm}$ long, terete, densely hairy; lamina small, elliptic to rhomboid, membranous, asymmetric, $2.5-5.5 \times 1.2-2.5 \mathrm{~cm}$, basifixed, base truncate on one side auriculate on the other, upper surface with evenly spaced bristles between the veins, underside densely hairy on the veins, hairs shorter than the bristles above, venation pinnate to palmatepinnate; margin dentate, slightly hairy, teeth 3-5 mm apart and c. $2 \mathrm{~mm}$ long; apex acute. Inflorescences terminal, total length 3-5 cm, a cyme of sub-umbellate cymes, branching 2 times, few (c. 5) flowered, bisexual, protandrous; primary peduncle $1 \mathrm{~cm}$ long, sparsely hairy; bracts deciduous, elliptic-lanceolate, $3.5 \times 1.5 \mathrm{~mm}$ wide, margin fimbriate. Male flowers: pedicel $10 \mathrm{~mm}$ long, with scattered hairs; tepals 4; outer tepals orbicular-obcordate, $11 \mathrm{~mm}$ in diameter, pinkish-white with deep pink on the reverse, upper tepal darker, not fleshy, with hairs denser towards the base, base slightly cordate becoming truncate when open, margin entire; inner tepals elliptic, $7 \times 3 \mathrm{~mm}$ wide, white; androecium yellow, loosely globose, symmetric, stamens $c$. 25 , on a short column; filaments subequal, $1.25-1.5 \mathrm{~mm}$ long, free; anthers narrowly oblong, c. $1.75 \mathrm{~mm}$ long, connective slightly retuse, hooded, dehiscing through slits about half the length of the anther, slits on the outer face of the anther. Female flowers: bracteoles present, lanceolate, $4 \times 1.5 \mathrm{~mm}$, fimbriate, 1-2 $\mathrm{mm}$ from the base of the ovary; pedicel 8-9 mm long, sparsely hairy; ovary pale pink, wings darker, with scattered stiff bristles on the capsule; capsule ellipsoid, $5 \times$ $3 \mathrm{~mm}$, 3-locular, placentae bifid; wings 3, equal, triangular, c. $3 \mathrm{~mm}$ wide; tepals 5, subequal, elliptic, c. $8 \times 4 \mathrm{~mm}$, upper petal pink, deeper pink on reverse, lower 4 tepals paler pink to white, glabrous, margin entire, persistent and closed during fruit ripening; stigma yellow, crescent shaped with the ends spiralled slightly, styles 3, deciduous. Fruit 1-2 in number, recurved at maturity on a c. $10 \mathrm{~mm}$ pedicel, turning red before drying brown, total size $13 \times 10 \mathrm{~mm}$; capsule elliptic, $8 \times 4 \mathrm{~mm}$, glabrous; wings subequal, triangular, $4 \times 8 \mathrm{~mm}$; apex obtuse to truncate.

\section{Distribution and habitat}

Only known from the forests in Kapahiang Regency in Bengkulu (Fig. 4). Found growing in small colonies by the roadside, near a damp ditch in the shade of other herbs.

\section{Conservation status}

The fact that this species has some ability to cope with secondary habitats may make it less likely to become threatened. However it is only known from one locality, and hence is best considered as Vulnerable under VUD2 (IUCN 2012) as the only known locality is not in a gazetted protected area.

\section{Begonia karangputihensis Girm. sp. nov. § Reichenheimia urn:Isid:ipni.org:names:77151643-1}

Figs 2, 8

\section{Diagnosis}

Begonia karangputihensis differs from the peltate B. goegoensis which is also native to West Sumatra in being a smaller plant, with smaller (up to $7 \mathrm{~cm}$ wide, not $c .9-15 \mathrm{~cm}$ wide), less rugose leaves, terete petioles (not triangular) and flowers with flat membranous tepals (not cup-shaped and fleshy).

\section{Etymology}

The epithet is derived from Bukit Karang Putih, an area of limestone within Lubuk Kilangan district, West Sumatra, near the Semen Padang mine. In English the name of the area means "white coral hill". 


\section{Type}

SUMATRA: West Sumatra, Bukit Karang Putih, near Padang, 364 m, 17 Jun. 2011, Puglisi, Hughes, Girmansyah \& Roki CP53 (holo-: BO; iso-: E).

\section{Additional material}

SUMATRA: West Sumatra, Bukit Karang Putih, 16 Feb. 1981, Hotta et al. 345 (ANDA); ibid., 28 Mar. 1989, Masniati 01 (ANDA); ibid., 17 Jul. 2011, Puglisi et al. CP57 (BO, E).

\section{Description}

Erect lithophytic acaulescent herb, 15-20 cm tall, often found in shallow caves; stem rhizomatous, internodes $0.5-1 \mathrm{~cm}$ long. Stipules persistent, glabrous, $10 \mathrm{~mm}$ long, broadly triangular, keeled only towards the apex, apex acute. Leaves: petiole $8-15 \mathrm{~cm}$ long, terete, glabrous; lamina basifixed on juvenile plants and peltate on mature individuals, basifixed leaves with base cordate, lobes not overlapping, peltate leaves ovate, subsymmetric to symmetric, $8.5-11 \times 5-7 \mathrm{~cm}$, upper surface light green, flushed reddish in centre on mature plants, glabrous on both sides, venation palmate-pinnate with $7(-8)$ main veins; margin sub entire to shallowly dentate, with cartilaginous recurved teeth at the end of the veins,

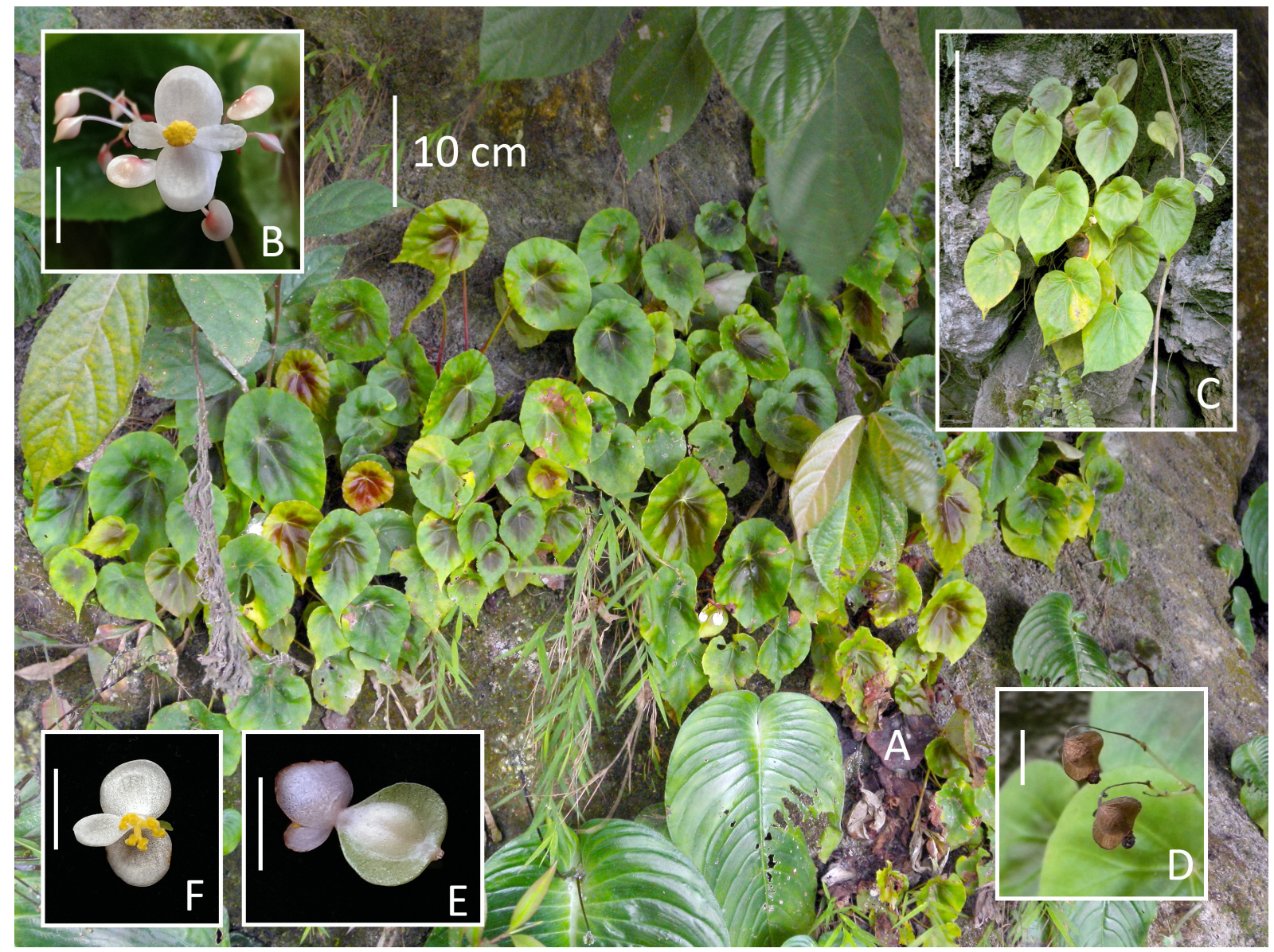

Fig. 8. Begonia karangputihensis Girm. sp. nov. A. Habit. B. Male flower. C. Plant with young leaves showing transition from basifixed to peltate. D. Mature fruit on a recurved pedicel. E. Ovary. F. Female flower. A,C, D taken at the type locality of Bukit Karang Putih; the floral insets B, E, F were photographed from plants in cultivation at the Royal Botanic Garden Edinburgh, accession 20111545. Scale bars on insets: $\mathrm{B}, \mathrm{D}-\mathrm{F}=1 \mathrm{~cm} ; \mathrm{C}=10 \mathrm{~cm}$. 
apex acute to shortly acuminate. Inflorescences axillary, total length $15-20 \mathrm{~cm}$, cymose, branching 2-5 times, with 10-20 flowers, bisexual, protandrous; primary peduncle 12.5-17 cm long; bracts caducous, basal pair sub-orbicular, $5 \times 4 \mathrm{~mm}$, subsequent pairs obovate, c. $3 \mathrm{~mm}$ long, margin entire. Male flowers: pedicel 10-18 mm long, glabrous; tepals 4; outer tepals 2, sub orbicular, membranous, $9 \times 9 \mathrm{~mm}$, white blushing pink at the base adaxially, glabrous, inner tepals elliptic, $7 \times 3 \mathrm{~mm}$, white; androecium yellow, globose, on a $0.5 \mathrm{~mm}$ long column; stamens 70-80; filaments unequal, basal ones shortest, $0.25-0.75 \mathrm{~mm}$ long; anthers $0.6 \mathrm{~mm}$ long, oblong-obtriangular, dehiscing through slits the whole length of the anther, slits positioned laterally. Female flowers: pedicel 10-15 mm long, glabrous; ovary green, glabrous, $10 \times 10 \mathrm{~mm}$ including the wings; capsule ellipsoid, $8 \times 4 \mathrm{~mm}$, ellipsoid, 3-locular, placentae entire; wings 3 , subequal, $10 \times 2 \mathrm{~mm}$, rounded, 2 slightly smaller ones rounded at the base, the other retuse; tepals 3-4, outer tepals $2,8 \times 8 \mathrm{~mm}$, suborbicular, white, inner tepals $1-2$, elliptic, $7 \times 3 \mathrm{~mm}$, white; stigmas 3 , deep yellow, forked once and once spirally twisted, semi-persistent. Fruit recurved on a stiff 10-20 mm long pedicel, the two smaller wings held horizontally forming a splash cup; total size 6-9 × 9-14 mm, wings 2-4 mm wide; apex obtuse.

\section{Distribution and habitat}

Endemic to the Bukit Karang Putih limestone near Padang in West Sumatra (Fig. 2), where it grows on cliffs and in shallow caves.

\section{Conservation status}

We assess B. karangputihensis to be Vulnerable under criteria VUD2 (IUCN 2012), as the type locality is only 1 kilometre away from an industrial limestone mine and just outside the edge of Kerinci Seblat National Park.

\section{Begonia kemumuensis M.Hughes sp. nov. § Reichenheimia urn:lsid:ipni.org:names:77151644-1}

Figs 4,9

\section{Diagnosis}

Vegetatively B. kemumuensis is most similar to B. stictopoda Miq. (A. DC) (de Candolle 1864) in habit, although the leaves are acutely lobed (not entire) and the flowers are smaller (largest tepal c. $5 \mathrm{~mm}$ across, not $c .10 \mathrm{~mm}$ ) with fleshy, cup-shaped tepals (not membranous flat tepals). The obtriangular anthers are also distinctive (elliptic in B. stictopoda).

\section{Etymology}

The epithet is derived from the locality where this species was discovered, near the village of Kemumu.

\section{Type}

SUMATRA: Bengkulu, Bukit Daun, Kemumu waterfall, 380 m, 18 Aug. 2010, Girmansyah \& Hughes DEDEN1506 (holo-: BO; iso-: E).

\section{Description}

Erect acaulescent herb, 15-20 cm tall; stem rhizomatous, internodes c. $5 \mathrm{~mm}$ long, sparsely hairy, becoming glabrous with age. Stipules persistent, hairy on the keel, triangular, apex filiform. Leaves: petiole 7-10 cm long, terete, with $5 \mathrm{~mm}$ long white erect hairs and an undercoat of shorter appressed hairs; lamina, suborbicular, thin, asymmetric, 10-13 $\times 9-11 \mathrm{~cm}$, basifixed, base cordate, sinus $c .1 .5 \mathrm{~cm}$, lobes overlapping, upper surface glabrous, underside with $1.5 \mathrm{~mm}$ long hairs on the veins, otherwise glabrous, venation palmate; margin sparsely denticulate, with 2-6 pointed short lobes c. 5-10 mm long. Inflorescences axillary, total length up to $c .25 \mathrm{~cm}$, cymose, branching $c$. 4 times, with $c .30$ 
flowers, bisexual, protandrous, primary peduncle $17-22 \mathrm{~cm}$ long, puberulent; bracts deciduous, basal pair suborbicular, c. $4 \times 4 \mathrm{~mm}$, with $1 \mathrm{~mm}$ long hairs, fimbriate, becoming obovate, smaller, entire and glabrous towards the inflorescence apex. Male flowers: pedicel c. $20 \mathrm{~mm}$ long for the first flower in the centre of the cyme, shorter to $c .4 \mathrm{~mm}$ long in the more distal parts, puberulent; tepals 4; outer 2 pink adaxially, fleshy, ovate, $5 \times 4 \mathrm{~mm}$; inner 2 white, membranous, elliptic $4 \times 2 \mathrm{~mm}$; androecium yellow, globose-cylindrical, symmetric, stamens $c$. 100, on a $2 \mathrm{~mm}$ long column; filaments subequal, $0.5 \mathrm{~mm}$; anthers obtriangular, $0.5 \mathrm{~mm}$ long, connective retuse, dehiscing through slits the length of the anther, slits lateral. Female flowers not seen. Fruit recurved on a 5-8 mm long stiff pedicel, total size $4-6 \times$

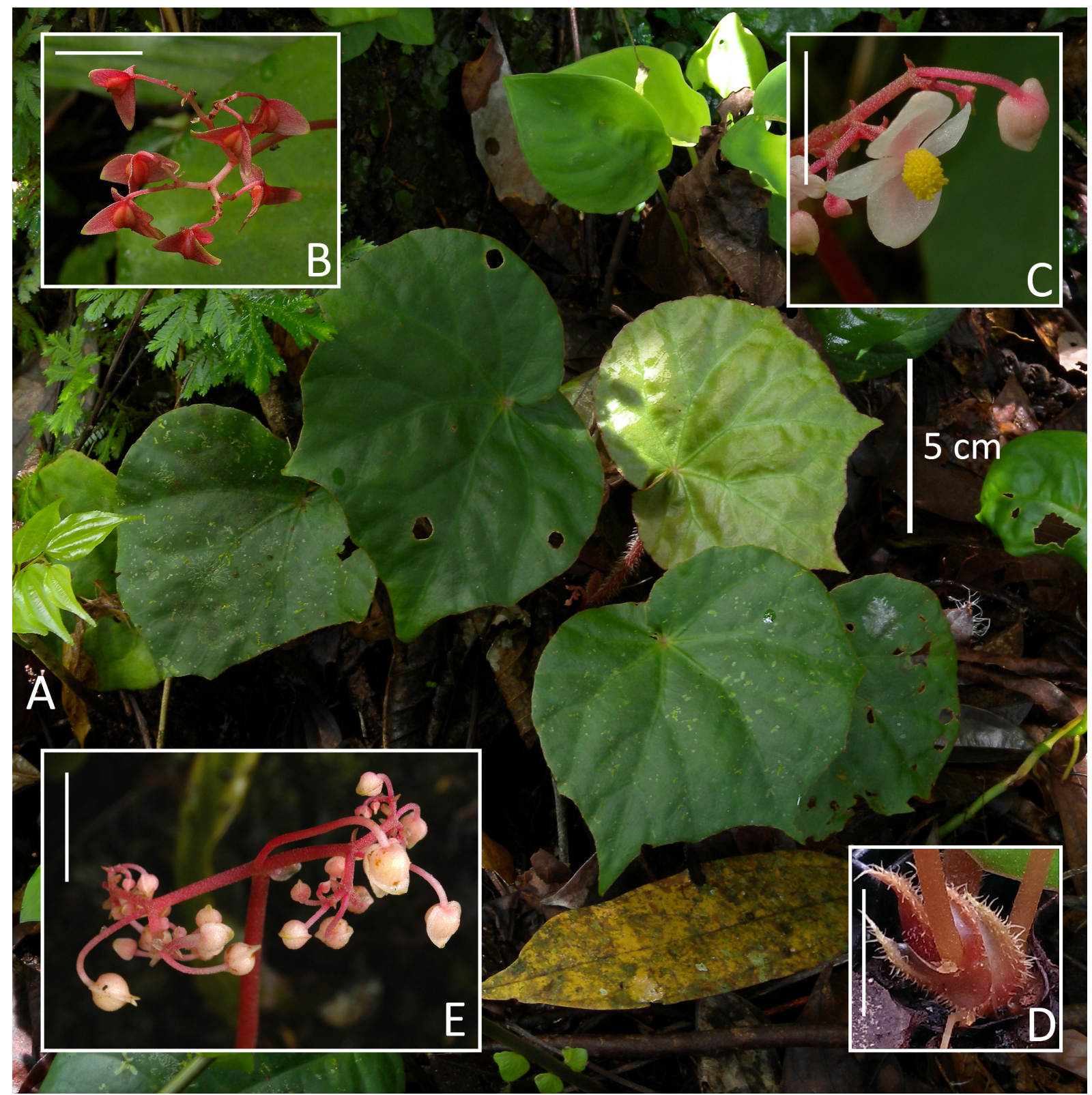

Fig. 9. Begonia kemumuensis M.Hughes sp. nov. A. Habit. B. Fruit. C. Male flower. D. Stipules. E. Young inflorescence. A-C, E from the type locality of Kemumu waterfall; D from a plant in cultivation at the Royal Botanic Garden Edinburgh (accession 20101656, derived from the type DEDEN1506). Scale bars on insets $=1 \mathrm{~cm}$. 
10-12 mm, capsule orbicular, $5 \mathrm{~mm}$ in diameter, wings equal, rounded-triangular, c. $7 \mathrm{~mm}$ long; apex abtuse to truncate.

\section{Distribution and habitat}

Known only from the type locality along a forest trail near the old concrete dam by Kemumu waterfall in Bengkulu Province (Fig. 4).

\section{Conservation status}

Known from a single location which is currently a well-managed recreation forest. The single location means the species is prone to the risk of extinction through chance events, so we consider the IUCN category of Vulnerable to apply using criterion VUD2 (IUCN 2012).

\section{Begonia korthalsiana Miq. ex M.Hughes sp. nov. § Reichenheimia} urn:lsid:ipni.org:names:77151645-1

Figs 4,10

\section{Diagnosis}

The red, fleshy bristles at the petiole apex are an unusual character in Asian Begonia and demonstrate an alliance of this species with B. sublobata Jack (Jack 1822) and B. fluvialis sp. nov.; B. korthalsiana sp. nov. differs considerably from both in its larger, unlobed ovate-orbicular leaves $(18-24 \times 15-20 \mathrm{~cm}$, c. $12 \times 12 \mathrm{~cm}$ in $B$. sublobata) and much larger inflorescences $(c .60 \mathrm{~cm}$ long with $c .100$ flowers $v s . c$. $15 \mathrm{~cm}$ long with $c$. 30 flowers in B. sublobata). The male flowers were described from sketches made by Irmscher in Berlin; the material is sparse and whether the flowers consistently have 2 tepals needs confirmation; the smaller size of the female flowers is probably due their immaturity.

\section{Etymology}

Named after the Dutch botanist Pieter W. Korthals [1807-1892] who was the first person to collect this species, with the specimens being later annotated by Miquel. The specimens collected by Beccari were chosen as the type as they had better fruiting material.

\section{Type}

SUMATRA: West Sumatra, Padang, Kayu Tanam, 130 m, Sep. 1872, Beccari PS857 (holo-: L [no. 898195], iso-: L, FI [3], B [3]).

\section{Additional material}

SUMATRA: Korthals s.n. (L [4]).

\section{Description}

Large erect acaulescent herb to $60 \mathrm{~cm}$ tall; stem a thick woody rhizome, internodes $0.5-1 \mathrm{~cm}$ long. Stipules persistent, glabrous, $25-30 \mathrm{~mm}$ long, lanceolate, with a filiform extension at the apex. Leaves: petiole 29-34 cm long, cross-section unknown, glabrous, with a semicircle of 10-15 stiff red c. $8 \mathrm{~mm}$ long bristles at the apex; lamina ovate-orbicular, asymmetric, 18-24 × 15-20 cm, basifixed, base cordate with lobes overlapping, sinus depth 20-30 mm, upper and lower surface glabrous, venation palmate; margin broadly crenate and denticulate, with recurved stiff teeth at the end of the veins; apex shortly acuminate. Inflorescences axillary, total length 50-60 cm, cymose, branching 4-6 times, many flowered, bisexual; primary peduncle $40 \mathrm{~cm}$ long, glabrous; bracts caducous, unknown. Male flowers: pedicel $15 \mathrm{~mm}$ long; tepals 2, orbicular, $11 \times 12 \mathrm{~mm}$, slightly cordate at the base, margin entire; androecium globose, with 80-100 stamens; filaments subequal, $1.5 \mathrm{~mm}$ long, fused at the base into a short column; anthers slightly shorter than the filament, oblong elliptic, connective slightly retuse, slightly hooded, 

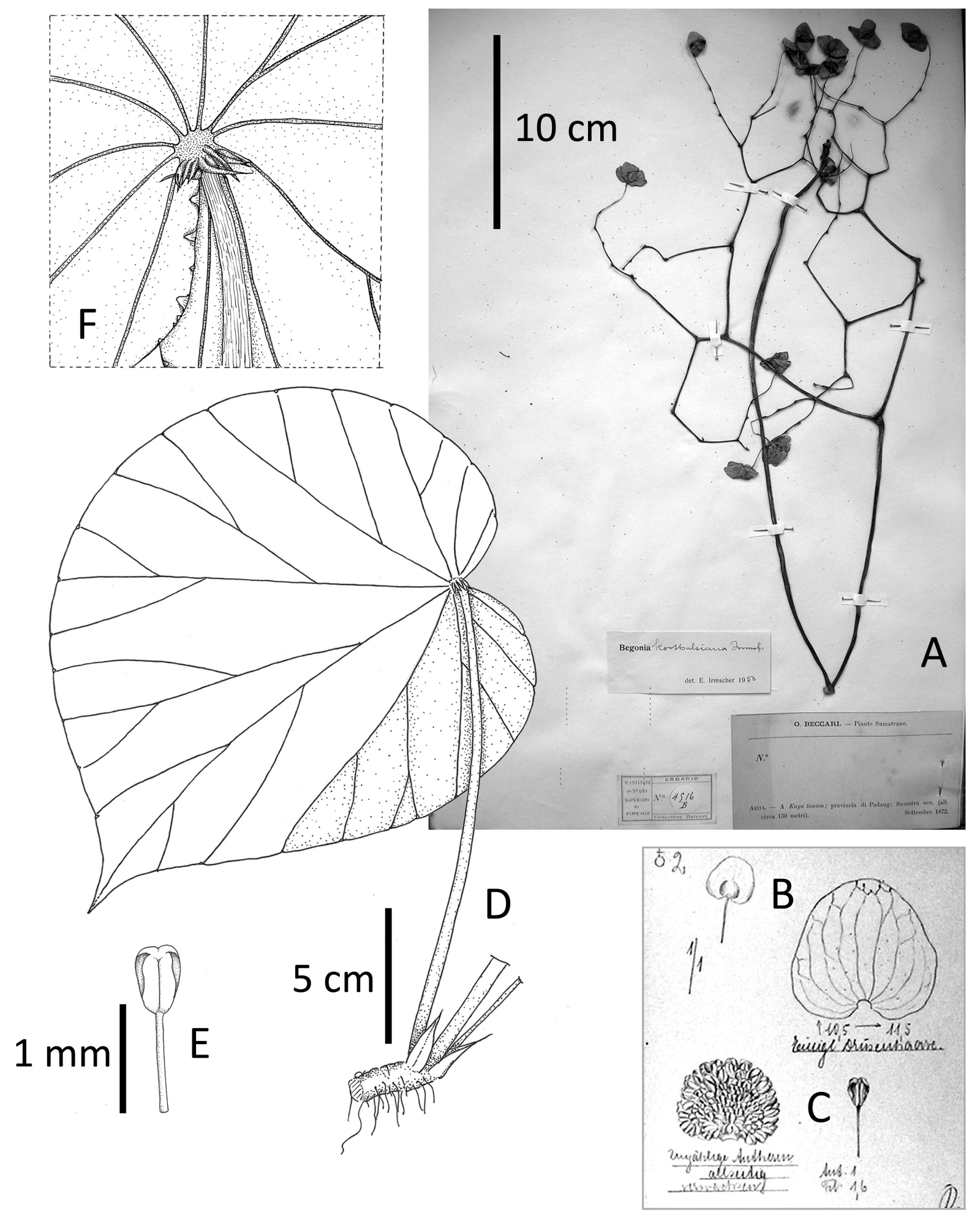

Fig. 10. Begonia korthalsiana Miq. ex M.Hughes sp. nov. A. Infructescence on isotype Beccari PS857 (FI). B. Male flower with pedicel (left), tepal of male flower (right). C. Androecium (left), anther (right). D. Rhizome and leaf. E. Anther. F. Leaf lamina underside at point of petiole attachment showing fleshy bristles. B, C drawn by E. Irmscher from isotype Beccari PS857 (B); D-F drawn by M. Hughes from isotype Beccari PS857 (FI). 
dehiscing through slits running nearly the entire length of the anther, the slits positioned on the outer face of the anther. Female flowers: pedicel $11 \mathrm{~mm}$ long; ovary glabrous, $6 \times 10 \mathrm{~mm}$ including wings; capsule elliptic, $5 \times 3 \mathrm{~mm}, 3$ locular, placentae entire; wings 3, subequal, rounded triangular; tepals 2 , orbicular, $6 \times 5 \mathrm{~mm}$, margin entire; styles 3 , stigmatic surface once spirally twisted, caducous. Fruit recurved on a $2-2.5 \mathrm{~cm}$ pedicel; wings subequal, rounded-triangular, $12 \times 18 \mathrm{~mm}$ in total; capsule elliptic, $9 \times 6 \mathrm{~mm}$, glabrous; apex obtuse.

\section{Distribution and habitat}

Frustratingly Korthals did not give a precise locality for his collection, which is the only other collection of this species apart from the type. Although he did visit Kayu Tanam ("Kajoetanam") on April $25^{\text {th }}$ 1834, where Beccari made his collection of this species, Korthals also visited many other locations in Sumatra. The species is likely endemic to Kayu Tanam in West Sumatra near Padang (Fig. 4).

\section{Conservation status}

As 140 years have passed since the last collection of this species, it seems reasonable to assume it is a very local and scarce endemic of low-altitude forest. As Kayu Tanam is now a mix of suburban and agricultural areas on the main road between Padang city and Padangpanjang, it is possible that B. korthalsiana is extinct. However there are still expanses of forest that need exploring between Kayu Tanam and Lake Singkarak before this is declared; until then we assess B. korthalsiana to be Data Deficient (IUCN 2012).

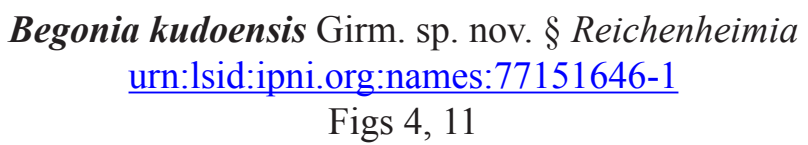

\section{Diagnosis}

Closest to B. halabanensis described above, sharing succulent peltate leaves, but differing in being glabrous, having fruit which are acute at the apex, and an erect succulent stem. The stem morphology is reminiscent of that found in B. wadei Merr. \& Quisumb. (Merrill \& Quisumbing 1932) from coastal limestone karst in Palawan, and B. viscosa Aver. \& H.Q.Nguyen (Averyanov \& Nguyen 2012) from crystalline limestone cliffs in central Laos; however both those species differ in having basifixed leaves.

\section{Etymology}

The epithet is derived from the name of the type locality, Gunung Batu Kudo in West Sumatra.

\section{Type}

SUMATRA: West Sumatra, Gunung Batu Kudo, 500 m, 19 Jun. 2011, Puglisi, Hughes, Girmansyah \& Roki CP67 (holo-: BO; iso-: E).

\section{Additional material}

SUMATRA: West Sumatra, Tanah Datar, Bukit Ngalau Pangian, 270-300 m, 6 Nov. 1993, Fitri, Hendrian et al. 35 (ANDA, E).

\section{Description}

Succulent lithophytic herb growing on limestone cliffs. Stem succulent, erect, a modified rhizome, internodes $c .1 \mathrm{~cm}$ long. Stipules persistent, glabrous, $12-20 \times 10-15 \mathrm{~mm}$, lanceolate, strongly keeled, with a filiform extension 1.5-2.0 cm long. Leaves: petiole 10-12(-30) cm long, terete, glabrous; lamina suborbicular, peltate, subsymmetric, succulent, glabrous, 11-17 ×9-14 cm, upper surface light green, some darker colour forms have a brownish purple lamina, paler and green at the veins, venation radial, 
with 10-11 main veins, margin with recurved stiff teeth at the end of the veins, slightly indented given a pseudo-crenate appearance, teeth rounded-obtuse, c. $1.5 \mathrm{~mm}$ long. Inflorescences in terminal axils, total length $c .15 \mathrm{~cm}$, cymose, branching around 4 times, $c .40$-flowered, bisexual, protandrous; primary peduncle $c .10 \mathrm{~cm}$ long; lower bracts elliptic, $c .4 \times 3 \mathrm{~mm}$, entire, upper bracts minute, semi-persistent; peduncles and flowers minutely and densely puberulent when very young, becoming glabrous when mature. Male flowers: pedicel c. $2.5 \mathrm{~cm}$ long; tepals 4, small, white, outer tepals 2, suborbicular, 5-7 $\times$ $5 \mathrm{~mm}$, inner tepals 2, elliptic, $5 \times 3 \mathrm{~mm}$; androecium globose, yellow, stamens $c$. 35 , outer anthers subsessile, inner anthers on filaments about the same length as the anther, anthers $0.75 \mathrm{~mm}$ long, obtriangular, apex retuse, dehiscing through lateral slits about half the length of the anther. Female flowers: pedicel $2.5 \mathrm{~cm}$ long; ovary green, glabrous, total size including the wings $2 \times 2.1 \mathrm{~cm}$ heartshaped, apex pointed, base retuse; capsule broadly ellipsoid, $11 \times 9 \mathrm{~mm}$, three locular, placentae entire; wings three, equal, rounded; tepals same as in the male flower; stigmas 3, yellow, Y-shaped, surface once spirally twisted. Fruit pendent on a thin $2.5 \mathrm{~cm}$ long pedicel, size and shape as for the ovary; apex obtuse.

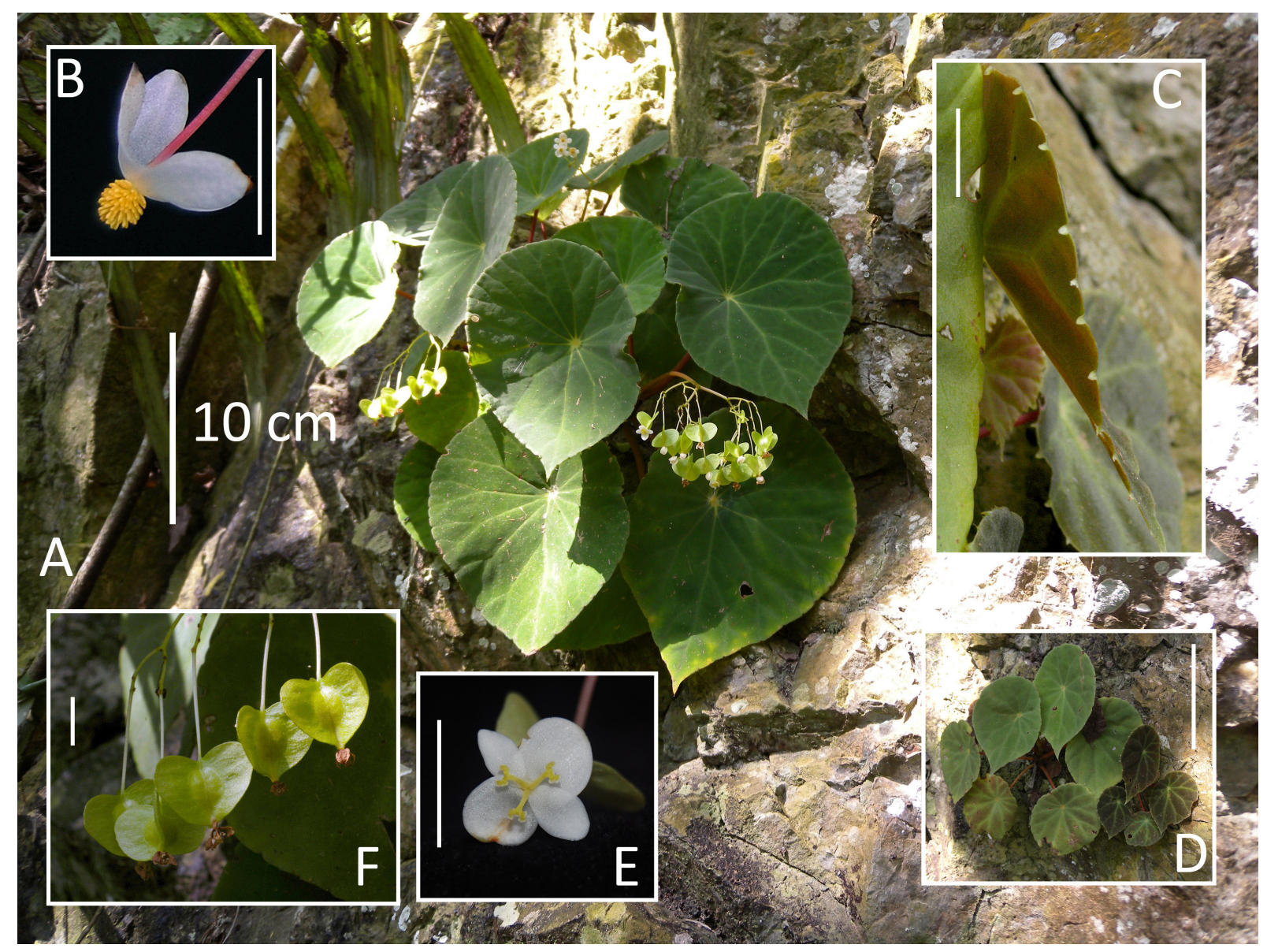

Fig. 11. Begonia kudoensis Girm. sp. nov. A. Habit (Gunung Batu Kudo, type collection Puglisi et al. CP67). B. Male flower, from cultivated plant in Bali Botanic Garden derived from CP67. C. Leaf lamina edge showing recurved teeth. D. Whole plants showing different colour forms. E. Female flower from cultivated plant in Bali Botanic Garden derived from CP67. F. Fruit on a pendulous pedicel (type collection Puglisi et al. CP67). C \& D taken at the type locality. Scale bars on insets: B, C, E, F = $1 \mathrm{~cm}$; $\mathrm{D}=5 \mathrm{~cm}$. 


\section{Distribution and habitat}

Known only from the type locality at Batu Kudo in West Sumatra (Fig. 4), where it grows on bare vertical limestone cliffs at an altitude of 250-400 m.

\section{Conservation status}

The vegetation at the base of the cliffs is disturbed and is being encroached by coffee plantations. The succulent leaves and stems mean the species is adapted to dryer conditions and seems to cope in the current conditions, although further disturbance to tree cover near to the cliffs should be discouraged. In combination with the very narrow distribution of B. kudoensis this means an IUCN category of Vulnerable is appropriate, under VUD2.

Begonia leuserensis M.Hughes sp. nov. § Platycentrum urn:lsid:ipni.org:names:77151647-1

Figs 2, 12

\section{Diagnosis}

Differs from B. teysmanniana Miq.(Tebbit) (Tebbitt \& Dickson 2000) in being a lower growing plant (c. $30 \mathrm{~cm}$ tall, not $c .60-80 \mathrm{~cm}$ ) with lobed leaves (not entire) having dense red hairs on the leaf veins (not white sparsely puberulent), and differs from B. areolata Miq. (Miquel 1855) in having leaves which are smooth above (not densely bullate). Begonia leuserensis differs from both in having 6 (not 5) tepals in the female flowers.

\section{Etymology}

The epithet is derived from the type locality of Gunung Leuser National Park, to where the species is endemic.

\section{Type}

SUMATRA: Aceh, Gunung Leuser Nature Reserve, Air Panas, 517 m, 19 Mar. 2008, Wilkie, Hughes, Sumadijaya, Rasnovi, Marlan \& Suhardi PW791 (holo-: BO; iso-: E).

\section{Additional material}

SUMATRA: Aceh, Gunung Leuser Nature Reserve, Air Panas, 433 m, 18 Mar. 2008, Wilkie et al. PW778 (BO, E, SING); Aceh, Gunung Leuser Nature Reserve, Bukit Ketambe, 800 m, 16 Mar. 2008, Wilkie et al. $P W 739(\mathrm{BO}, \underline{\mathrm{E}}, \mathrm{SING})$.

\section{Description}

Repent caulescent herb on earth banks, c. $30 \mathrm{~cm}$ tall. Stem with dense red short fleshy hairs, becoming nearly glabrous with age, rhizomatous at base with short internodes $<1 \mathrm{~cm}$ long, becoming longer (to c. $25 \mathrm{~cm}$ long) on flowering stems. Stipules persistent, with fine hairs, denser at the base, lanceolate, $2 \times 1 \mathrm{~cm}$, apex long acuminate. Leaves: petiole 4-25 cm long, terete, the longer petioles being borne on the rhizomatous part of the stem, densely red hairy; lamina asymmetric, broadly ovate, lobed, divided up to $1 / 2$ the way to the midrib, $8-18 \times 5-14 \mathrm{~cm}$, basifixed, base cordate, sinus $1-5 \mathrm{~cm}$ deep, upper surface glossy, nearly glabrous except for a few short fleshy hairs, under surface with dense red short hairs on the veins; margin denticulate, sparsely hairy. Inflorescences terminal, subtended by a pair of leaves, cymose, with $c$. 10 flowers, protandrous, bisexual; primary peduncle $8-12 \mathrm{~cm} \mathrm{long}$, red hairy; bracts: lanceolate, basal pair fused, tipped with a fringe of several points, $1-3 \mathrm{~cm}$ long, hairy at the base externally, bracts in the rest of the inflorescence much smaller. Male flowers: pedicel $15 \mathrm{~mm}$ long, hairy; tepals 4 , outer 2 tepals ovate, $20 \times 15 \mathrm{~mm}$, white, red hairy externally, entire, inner 2 tepals elliptic, 


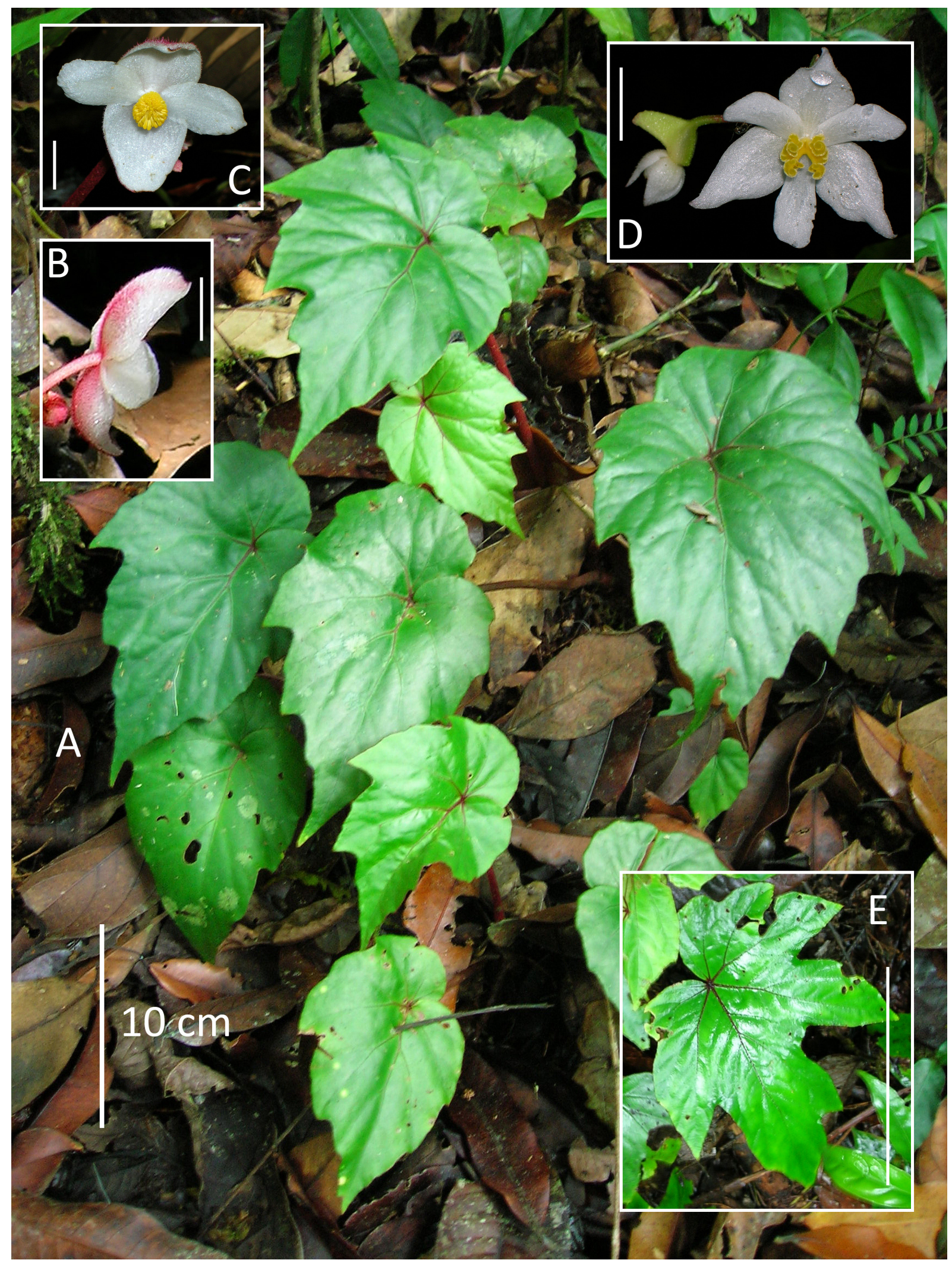

Fig. 12. Begonia leuserensis M.Hughes sp. nov. A. Habit. B. Male flower back view. C. Male flower. D. Female flower. E. Lobed leaf. A-D from Air Panas of the type collection Wilkie et al. PW791; E from $P W 778$. Scale bars on insets: $\mathrm{B}-\mathrm{D}=1 \mathrm{~cm} ; \mathrm{E}=10 \mathrm{~cm}$. 
$14 \times 7 \mathrm{~mm}$, white, glabrous; androecium with c. 100 stamens; filaments subequal, shorter on the basal stamens, up to $1.5 \mathrm{~mm}$ long, anthers $1.5 \mathrm{~mm}$ long, ellipsoid, wider at the apex, connective extended slightly, rounded. Female flowers: pedicel $15 \mathrm{~mm}$ long, hairy; ovary green, with dense short hairs, total size including wings $15 \times 22 \mathrm{~mm}$; capsule ellipsoid, 2-locular, placentae unknown; wings 3, unequal, one large and two smaller, rounded-triangular; tepals 6 , outer 3 ovate-lanceolate, white, $15 \times 9 \mathrm{~mm}$, red or white hairy externally, inner 3 elongate-obovate, glabrous; stigmas 2, bifid, greenish yellow, surface convolute. Fruit usually borne in pairs, recurved on a stiff pedicel c. $2.5 \mathrm{~cm}$ long; largest wing triangular, $2 \mathrm{~cm}$ long, outline slightly curved, thick and corky, smaller two wings forming a splash cup, triangular, $12 \mathrm{~mm}$ long; apex truncate.

\section{Distribution and habitat}

Endemic to Gunung Leuser National Park (Fig. 2), found on steep slopes on the forest floor at 400-800 $\mathrm{m}$ altitude, where it grows in leaf litter around rotting logs and at the base of trees.

\section{Conservation status}

Currently the montane forests in Gunung Leuser National Park are not under pressure, and the two known locations for the species are in the centre of the reserve. It seems likely that the species may be found on other nearby peaks at similar altitudes. We consider an IUCN category of Least Concern to be appropriate.

\section{Begonia lilliputana M.Hughes sp. nov. § Reichenheimia urn:Isid:ipni.org:names:77151648-1}

Figs 4,13

\section{Diagnosis}

This diminutive species differs from the only other known Sumatran rheophytic begonia, Begonia fluvialis (see above), in its smaller stature (leaves $3 \mathrm{~cm}$ long, not $8-15 \mathrm{~cm}$ long), by lacking bristles at the petiole apex and having barely peltate leaves (not minutely cordate). The other geographically nearest rheophytic species from Peninsular Malaysia [B. abdullahpieei Kiew, B. aequilateralis Irmsch., B. klossii Ridl., B. perakensis King, B. rhoephila Ridl. and B. rhyacophila Kiew (Irmscher 1929; Kiew 2005; King 1902; Ridley 1917)] all belong to Begonia sect. Platycentrum and differ in being larger plants with 2-locular fruits.

\section{Etymology}

The name is derived from the adjective lilliputian (English) meaning very small, derived from the name of the fictional island nation of Lilliput.

\section{Type}

SUMATRA: Aceh, Soraya Research Station, 50 m, 3 Feb. 1999, Argent 9938 (holo-: A).

\section{Description}

Diminutive acaulescent lithophytic riverine herb growing on rocks near waterfalls, $c .8 \mathrm{~cm}$ in height; stem rhizomatous, $2 \mathrm{~mm}$ in diameter, internodes $2-4 \mathrm{~mm}$ long. Stipules persistent, glabrous, $4-5 \times$ $2 \mathrm{~mm}$, lanceolate, with a filiform extension at the apex. Leaves: petiole $3 \mathrm{~cm}$ long, tomentose, crosssection unknown, rapidly becoming sub-glabrous with age; lamina minutely peltate, base rounded, elliptic-rhomboid, subsymmetric, c. $3 \times 1 \mathrm{~cm}$, upper surface glabrous, lower surface with dense hairs on veins only, venation palmate-pinnate, veins prominent above and below; margin minutely and sparsely denticulate; apex acute. Inflorescences axillary, total length 6-8 cm, cymose, branching 2-3 times, 3-4 flowered, bisexual, protandrous; primary peduncle 5-7 cm long, with sparse long hairs; bracts 
minute, elliptic-lanceolate with an extended tip, 1-1.5 mm long. Male flowers: pedicel $10 \mathrm{~mm}$ long, with scattered glandular hairs; tepals 4; outer tepals ovate-elliptic, $3 \times 2 \mathrm{~mm}$, pink or white, fleshy, with scattered glandular hairs on the outside, margin with a distinct rim; inner tepals elliptic, $2 \times 1 \mathrm{~mm}$; androecium globose; stamens $c$. 60; filaments equal, $0.5 \mathrm{~mm}$ long, fused at base into a column; anthers about as long as the filaments; ellipsoid-obtriangular, $0.5 \mathrm{~mm}$ long, connective slightly retuse, dehiscing through slits about half the length of the anther, with one slit on each side of the anther. Female flowers unknown. Fruits solitary, recurved on a $13 \mathrm{~mm}$ long pedicel; total size $10 \times 6 \mathrm{~mm}$; wings roundedtriangular, $3 \times 6 \mathrm{~mm}$, equal; capsule spherical, 3-4 mm in diameter, glabrous; apex obtuse.

\section{Distribution and habitat}

Currently known only from the type locality near the Soraya Research Station (Fig. 4) in Gunung Leuser National Park, where it grows as a rheophyte tightly attached to rocks at the base of waterfalls, in the shade of overhanging trees.

\section{Conservation status}

Begonia lilliputana is assessed as Data Deficient (IUCN 2012) as its full range within the Gunung Leuser National Park is unknown; the Soraya Research Station is on the southernmost edge of the core reserve.

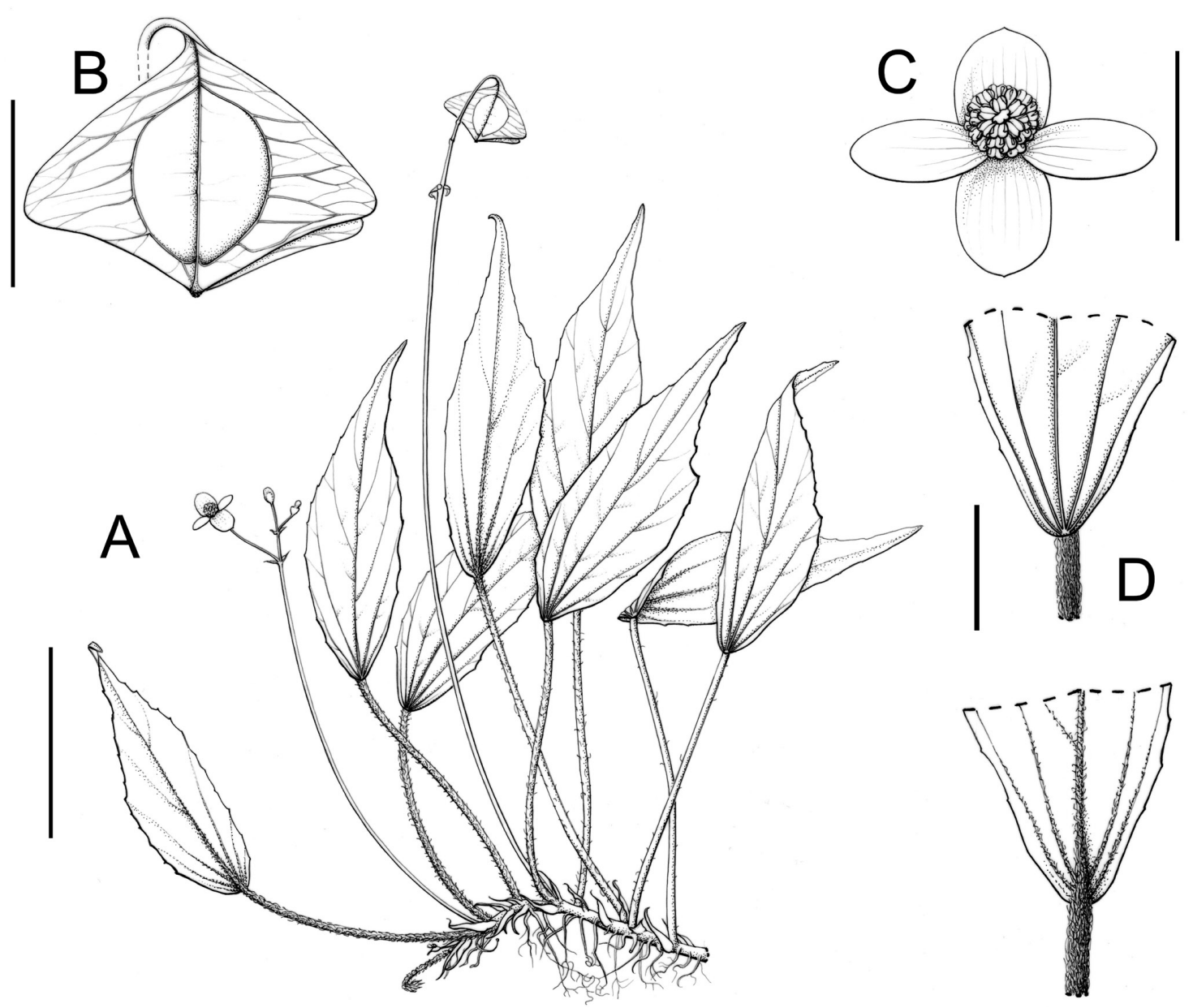

Fig. 13. Begonia lilliputana M.Hughes sp. nov. A. Habit. B. Mature fruit. C. Male flower. D. Leaf base upper (top) and lower (bottom) surface. All drawn from the holotype [Argent 9938 (A)] by Claire Banks. Scale bars: $\mathrm{A}=2 \mathrm{~cm} ; \mathrm{B}-\mathrm{D}=5 \mathrm{~mm}$. 


\section{Begonia olivacea Ardi sp. nov. §. Reichenheimia urn:lsid:ipni.org:names:77151649-1}

Figs 4,14

\section{Diagnosis}

The nearest species morphologically to Begonia olivacea is B. nurii Irmsch. (Irmscher 1929) from Kelantan in Peninsular Malaysia, the former differing in being a slightly smaller plant (leaves 2.7-4.5 $\times$ 2.6-3.7 cm, not c. $4 \times 4-6 \mathrm{~cm}$ ), having 3 (not 2) tepals in the female flowers, sparsely hairy petioles (not red-woolly), and duller green leaves (Kiew 2005). Also similar is B. droopiae Ardi (Ardi \& Hughes 2010) from limestone in West Sumatra, which has more asymmetric leaves with darker variegation, and which is smoothly bullate between the veins (not mostly flat). See under B. simolapensis for a comparison with that species.

\section{Etymology}

The epithet reflects the dull greenish brown olive colour of the leaves.

\section{Type}

SUMATRA: North Sumatra Province, Leuser National Park, Simolap, 250 m, 9 Jul. 2011, Carmen Puglisi 230 (holo-: BO; iso-: E).

\section{Additional material}

SUMATRA: Aceh, Gajolandan, 600 m, 25 Feb. 1937, Van Steenis 9273 (BO); ibid., 600 m, 26 Feb. 1937, Van Steenis 9321 (L); Ketambe Research Station, Gunung Leaser Nature Reserve, 300-350 m, 9 Jun. 1979, de Wilde \& de Wilde Duyfjes 18002 (L).

\section{Description}

Lithophytic acaulescent herb. Stem rhizomatous, internodes very short c. 1-2 mm long. Stipules persistent, with $2 \mathrm{~mm}$ long hairs on the keel, $10 \mathrm{~mm}$ long, narrowly oblong, with a $3.5 \mathrm{~mm}$ long filiform extension at the apex. Leaves: petiole $2.5-9 \mathrm{~cm}$ long, terete, sparsely hairy; lamina suborbicular, asymmetric, $2.7-4.5 \times 2.6-3.7 \mathrm{~cm}$, basifixed, base cordate with lobes sometimes slightly overlapping, abaxially mid green on the veins, dark purplish green between, occasionally all green with a faint purplish tinge between the veins, glabrous, slightly prominent between the veins, coriaceous, adaxially with sparse hairs on veins only, primary veins 5-7, margin crenate and fringed with sparse short hairs and recurved stiff teeth at the end of the veins, apex rounded. Inflorescences axillary, cymose, branching 2 times, few flowered, bisexual, protandrous; peduncle $7.5-10.5 \mathrm{~cm}$ long, glabrous; bracts minute, caducous. Male flowers: pedicel 10-15 mm long, glabrous; tepals 4; outer tepals broadly ovate, 7-8 $\times 6-7 \mathrm{~mm}$, white, glabrous, slightly cordate at the base becoming truncate when open, margin entire; inner tepals narrowly obovate or elliptic, c. $7 \times 2 \mathrm{~mm}$, white; androecium pale yellow, symmetric, globose, on a $1.5 \mathrm{~mm}$ long column; stamens 35-40. Female flowers: pedicel c.14 mm long; ovary green, glabrous, total size including wings $c .5 \times 11 \mathrm{~mm}$; capsule ellipsoid, $5 \times 3 \mathrm{~mm}$, locules 3 , placentae entire; wings 3 , equal, rounded at base and sub cuneate at the apex, widest point at the middle, c. $4 \mathrm{~mm}$; tepals 3; outer tepals 2, 6.5-7 $\times 6 \mathrm{~mm}$, sub orbicular, white, glabrous; inner tepal 1, c. $5 \times 2.5 \mathrm{~mm}$, elliptic; stigmas 3, pale yellow-green, forked and once spirally twisted, caducous. Fruit recurved on a $17 \mathrm{~mm}$ long pedicel; total size $c .5 \times 16 \mathrm{~mm}$ including the wings, wings $5 \mathrm{~mm}$ wide; apex obtuse.

\section{Distribution and habitat}

North Sumatra and Aceh, Gunung Leuser National Park (Fig. 4). This species grows in meagre, dusty soil on limestone rock at $250-600 \mathrm{~m}$ altitude. 


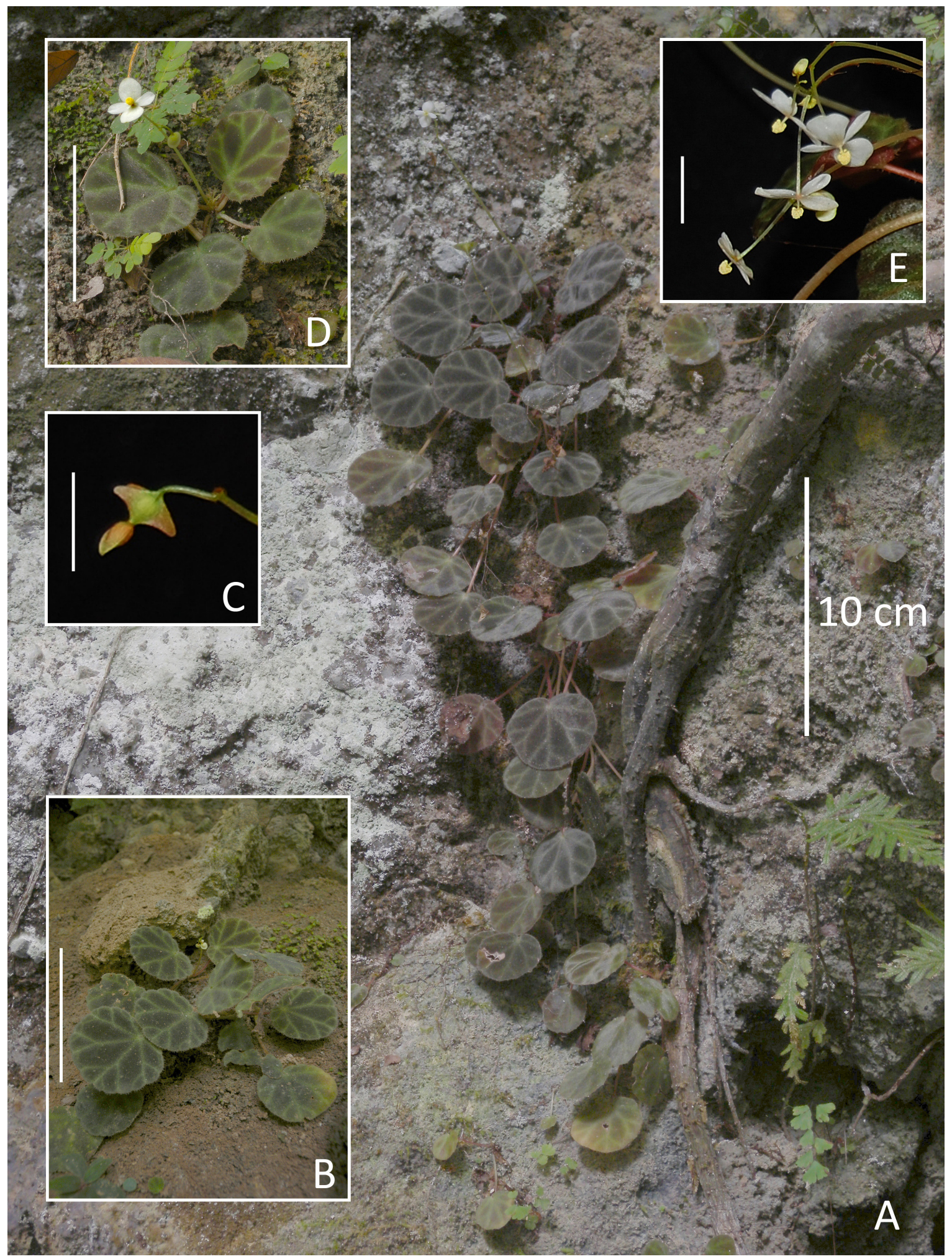

Fig. 14. Begonia olivacea Ardi sp. nov. A. Habit, showing petiole elongation in older leaves. B. Green colour form. C. Female flower bud and ovary. D. Plant with male flower. E. Male flowers. A, B, D photographed at the type locality of Simolap; C, E taken from a plant in cultivation at Bogor Botanic Garden (accession B2013070037, derived from material collected at the type locality). Scale bars on insets: $\mathrm{B}, \mathrm{D}=5 \mathrm{~cm} ; \mathrm{C}, \mathrm{E}=1 \mathrm{~cm}$. 


\section{Conservation status}

The limestone habitat of the Gunung Leuser National Park in the Simolap area where this species occurs is relatively intact. As long as this remains the case, B. olivacea can be considered as belonging to the IUCN category of Least Concern.

\section{Begonia pseudoscottii Girm. sp. nov. § Sphenanthera urn:lsid:ipni.org:names:77151650-1}

Figs 2, 15

\section{Diagnosis}

Differs from Begonia scottii Tebbitt (Tebbit 2005) in bearing fruit in clusters of 10-15 (not 2 or 4), with the fruit being fleshier and rounder, with ridges rather than small wings. The infructescence in terms of fruit number and shape is more similar to that of B. multangula Blume (Blume 1827), which has lobed leaves that are either subglabrous or have white hairs (not pink), and apical (not basal) more lax infructesences. The flowers have pink centres to the tepals (uniform white in B. scottii) and the leaves have deep pink hairs (not white).

\section{Etymology}

The epithet refers to the previous confusion of this species with B. scottii (Hughes \& Girmansyah 2011b).

\section{Type}

SUMATRA: Aceh, Boer ni Bias, 1300 m, 31 Aug. 1934, Van Steenis 6207 (holo-: BO).

\section{Additional material}

SUMATRA: North Sumatra, Gunong Batu Lopang, $10 \mathrm{~km}$ ESE of Lake Prapat, 1400-1500 m, 8 Jul. 1972, de Wilde \& de Wilde-Duyfies 13531 (BO, K); Aceh, Gunung Kemiri, 1696 m, 11 Mar. 2008, Wilkie et al. PW678 (E).

\section{Description}

Erect robust terrestrial herb $30-40 \mathrm{~cm}$ tall. Stem fleshy, repent at the base, rooting at the nodes, with simple white hairs, becoming glabrous with age. Stipules ovate-lanceolate, reddish, c. $15 \times 9 \mathrm{~mm}$, apex acuminate, keel with sparse short hairs. Leaves: petiole 16-26 cm long, terete, with dense white to pale pink hairs; lamina ovate, asymmetric, $17-23 \times 14-18 \mathrm{~cm}$, upper surface with short dense hairs, hairs deep pink when young becoming paler with age, basifixed, base cordate with lobes sometimes overlapping slightly, venation palmate-pinnate, margin sometimes slightly undulate, serrulate, teeth tipped by short glandular hairs, apex acute. Inflorescence axillary, usually borne near the base of the stem, total length c. $5 \mathrm{~cm}$, a congested cyme, bisexual, with 10-25 flowers, male and female flowers open at the same time. Male flowers: pedicels with sparse minute hairs, $3.1-3.3 \mathrm{~cm}$ long; tepals 4, subequal, elliptic, outer pair adaxially hairy, pink with a white margin, $1.3 \times 1-1.2 \mathrm{~cm}$; inner pair, glabrous, paler pink with a white margin, $1.2 \times 1 \mathrm{~cm}$; androecium yellow, symmetric, loosely globose; stamens $60-70$, filaments unequal, shorter in the basal stamens, anthers club-shaped, dehiscing through slits $c .3 / 4$ the length of the anther, slits lateral, connective extended. Female flowers: pedicels $8-10 \mathrm{~mm}$ long; ovary red, triangularglobose, sparsely hairy to glabrous, c. $10 \times 10 \mathrm{~mm}$; capsule 3-locular, placentae bifid; tepals 5 , obovateoblong, outer 3 c. $15 \times 8-13 \mathrm{~mm}$, pink with a white margin, sparsely adaxially hairy, inner 2 c. $15 \times$ $5 \mathrm{~mm}$, white, glabrous; styles 3, greenish yellow, twice spirally twisted. Fruit 10-15 in number, on stiff pedicels $c .2 \mathrm{~cm}$ long, purple, berry-like, $c .12 \times 15 \mathrm{~mm}$, triangular-globose, fleshy, 3-ridged; apex truncate to rounded. 


\section{Distribution and habitat}

In montane rainforest in North Sumatra and Aceh at altitudes of 1300-1700 m (Fig. 2).

\section{Conservation status}

Begonia pseudoscotti does not appear to be common, but does have a fairly large distribution in northern Sumatra. The preference for mid to high montane forests which are not under heavy threat means that currently an IUCN category of Least Concern is appropriate.

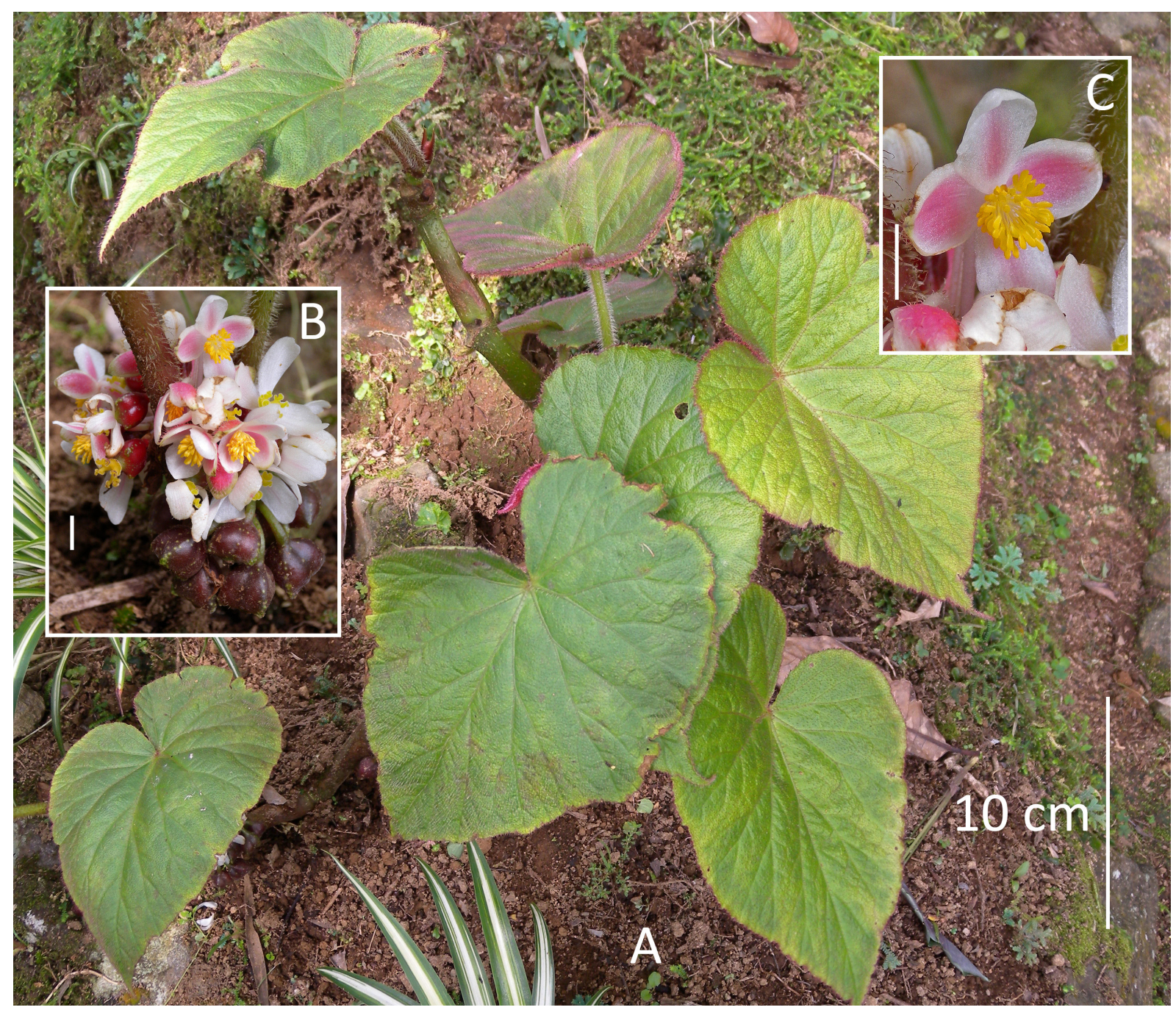

Fig. 15. Begonia pseudoscottii Girm sp. nov. A. Habit. B. Inflorescence at the base of the plant, with mature fruit below and male and female flowers open at the top. C. Male flower. All photographs from a plant cultivated in Cibodas Botanic Garden (accession number C20090980/IY80, derived from material collected in Gunung Leuser National Park). Scale bars on insets $=1 \mathrm{~cm}$. 


\section{Begonia raoensis M.Hughes sp. nov. § Reichenheimia \\ urn:1sid:ipni.org:names:77151651-1}

Figs 2, 16

\section{Diagnosis}

Begonia raoensis is similar in habit and leaf shape to mature plants of $B$. stictopoda Miq. (A.DC.), but differs in having petioles with red, erect hairs (not appressed fine brown hairs), hairy stipules and styles that are not as deeply forked and a stigmatic surface only once (not twice) spirally twisted. $B$. trichopoda Miq. (Miquel 1856) has hairy petioles and a similar habit, but in B. raoensis the hairs are shorter on the petioles (c. $3 \mathrm{~mm}$, not 6-9 mm) and not as dense, the peduncles are sparsely minutely puberulent (not densely hairy); also the leaves of $B$. raoensis are suborbicular with overlapping basal lobes (not broadly ovate with basal lobes not overlapping in B. trichopoda).

\section{Etymology}

The epithet refers to the village Rao nearby the type locality.

\section{Type}

SUMATRA: West Sumatra, road to Padang, Rao, 600 m, 18 May 2007, Hughes \& Girmansyah MH1400 (holo-: BO; iso-: E).

\section{Description}

Erect acaulescent herb to $30 \mathrm{~cm}$ tall, on steep rock banks; stem rhizomatous, glabrous, internodes c. $5 \mathrm{~mm}$ long. Stipules persistent, triangular, c. $10 \times 5 \mathrm{~mm}$, hairy on the keel, apex filiform, hairy. Leaves: petiole 4-21 cm long, terete, with dense erect red hairs, hairs becoming fleshy towards the petiole apex, forming a ring; leaf lamina on young plants smaller and ovate, on mature plants larger and suborbicular, 10-26 $\times 7-18 \mathrm{~cm}$, basifixed, base cordate, basal lobes overlapping on larger leaves, upper surface reddish green when young maturing to green, glabrous, lower surface glabrous apart from short scattered hairs on the veins; venation palmate with 9 main veins, veins prominent on the upper surface; margin subentire, denticulate with evenly spaced small stiff red teeth, sparsely hairy; apex acute. Inflorescences axillary, total length $c .20 \mathrm{~cm}$, cymose, protandrous, branching c. 5 times, with up to $c$. 40 flowers in larger plants, primary peduncle $12-17 \mathrm{~cm}$ long, sparsely minutely puberulent; bracts caducous, elliptic, $4 \times 1.5 \mathrm{~mm}$, margin entire. Male flowers: pedicel c. $6 \mathrm{~mm}$ long, glabrous, pink; tepals 4, white, glabrous, outer tepals 2 , membranous, orbicular-ovate, $8 \times 7 \mathrm{~mm}$; inner 2 elliptic-obovate, $8 \times$ $3 \mathrm{~mm}$; androecium yellow, globose, on a short column; stamens $c$. 50; filaments $0.5 \mathrm{~mm}$ long, subequal; anthers $0.5 \mathrm{~mm}$ long, obtriangular, apex retuse, dehiscing through lateral slits that run the whole length of the anther. Female flower: pedicel 7-21 mm long, glabrous; ovary pale pink, glabrous, $9 \times 15 \mathrm{~mm}$ in total including wings; capsule 3-locular, ellipsoid, $7 \times 6 \mathrm{~mm}$, placentae unknown; wings 3, subequal, rounded-triangular, largest wing $5 \mathrm{~mm}$ wide; tepals $3-4$, white; outer 2 tepals orbicular-ovate, $7 \times 6 \mathrm{~mm}$, glabrous; inner 1-2, elliptic, $6 \times 2 \mathrm{~mm}$; stigmas 3 , free, deep yellow, shallowly forked, stigmatic surface once spirally twisted. Fruit: pendent on a $2 \mathrm{~cm}$ long hair-like pedicel, shape as same as the ovary, $c .9 \times$ $16 \mathrm{~mm}$; apex obtuse.

\section{Distribution and habitat}

Only known from the type collection from a steep soil bank with some surface water and overhanging roadside scrubby vegetation in West Sumatra near Rao village (Fig. 2). 


\section{Conservation status}

The forest in the area is quite fragmented, and it would seem that the species is able to persist in these fragments. The area is not well collected and we know little about the distribution of the species, which we consider to be Data Deficient (IUCN 2012).

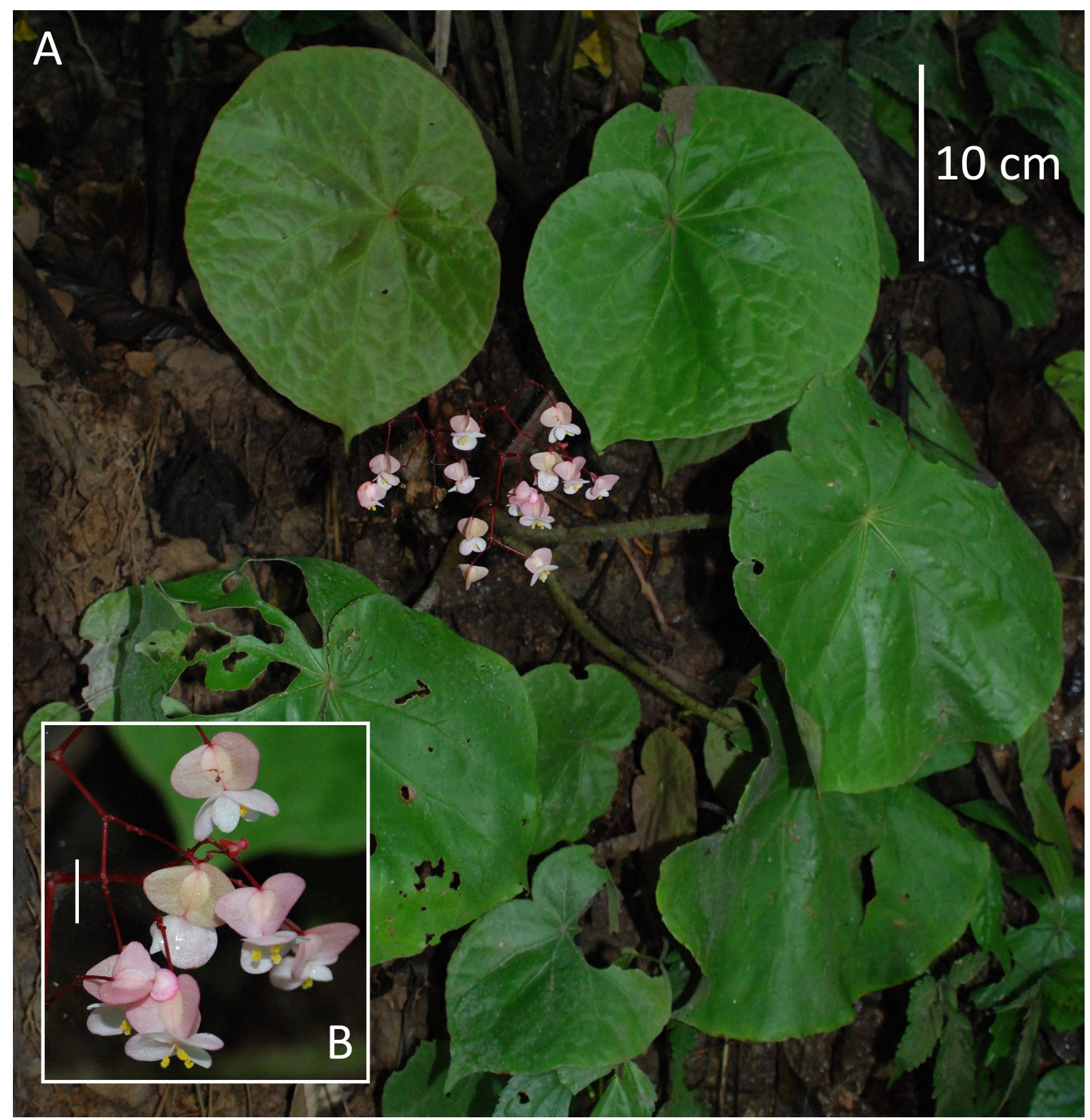

Fig. 16. Begonia raoensis M.Hughes sp. nov. A. Habit. B. Inflorescence in female phase (scale bar = $1 \mathrm{~cm})$. Photographs from the Rao vicinity, of the type Hughes \& Girmansyah MH1400. 
Begonia simolapensis Ardi sp. nov. § Reichenheimia

urn:Isid:ipni.org:names:77151652-1

Figs 2, 17

\section{Diagnosis}

Begonia simolapensis grows sympatrically on limestone with $B$. olivacea described above and has a similar habit (growing flat against the substrate) and leaf shape; it differs in having larger (5-9.5 $\times$ 4-8 cm, not $2.7-4.5 \times 2.6-3.7 \mathrm{~cm}$ ), glossier leaves which are a nearly uniform deep green (not olive green with paler variegation) and longer, denser hairs on the petioles.

\section{Etymology}

The epithet refers to the type locality of Simolap.

\section{Type}

SUMATRA: North Sumatra Province, Leuser National Park, Simolap, 260 m, 9 Jul. 2011, Puglisi et al. 228 (holo-: BO; iso-: $\underline{\text { E)}}$.

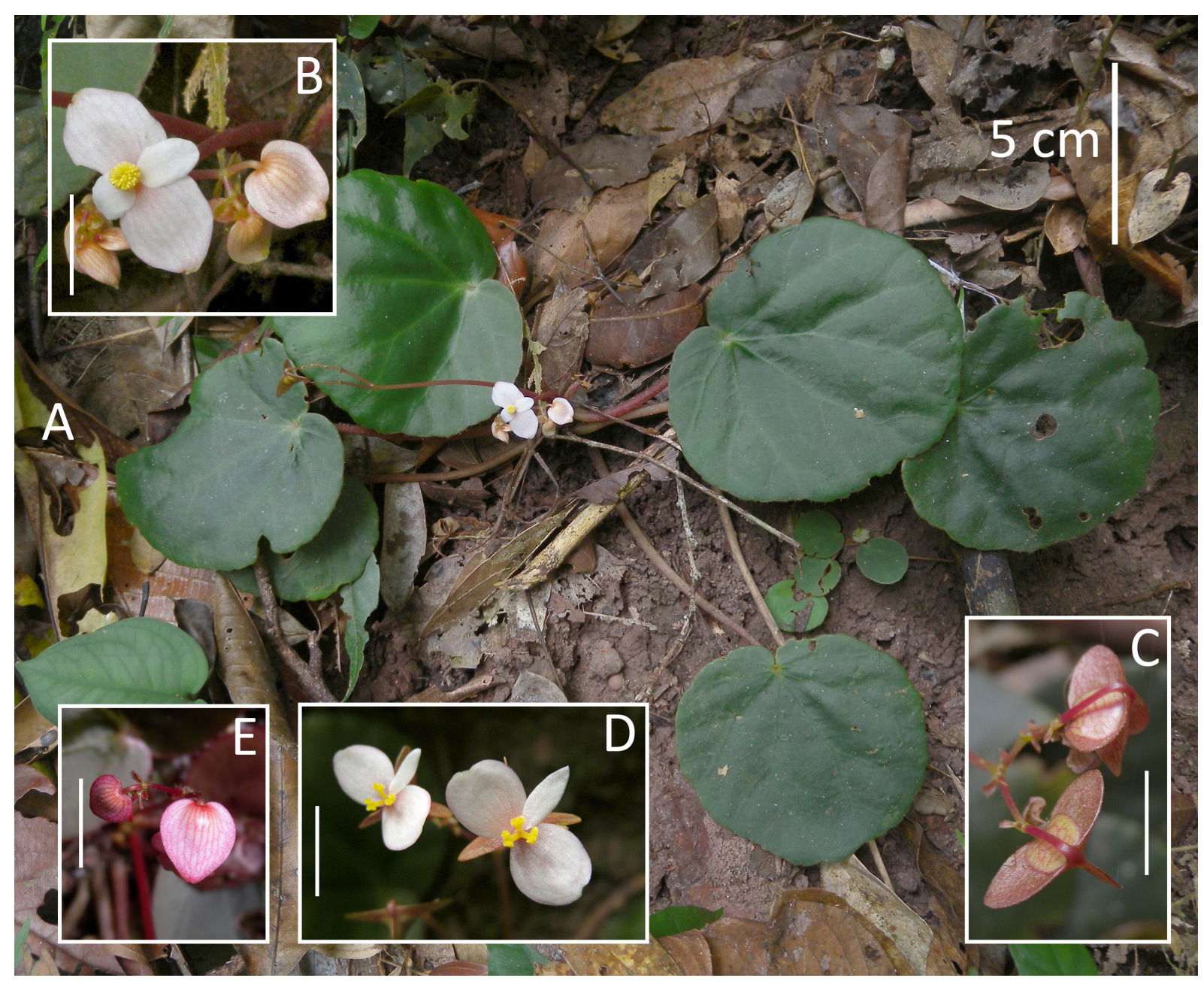

Fig. 17. Begonia simolapensis Ardi sp. nov. A. Habit. B. Male flower. C. Fruit on recurved pedicels. D. Female flowers. E. Male flower buds. All photographs from the type locality of Simolap. Scale bars on insets $=1 \mathrm{~cm}$. 


\section{Additional material}

SUMATRA: North Sumatra, Gunung Leuser National Park, Simolap, 11 Jul. 2011, Puglisi 267 (BO, E).

\section{Description}

Repent acaulescent herb, growing flat against vertical rocks or soil on limestone, less than $15 \mathrm{~cm}$ tall; stem rhizomatous, internodes c. $2 \mathrm{~mm}$ long. Stipules persistent, triangular, 4-5 $\times 5 \mathrm{~mm}$, with an abaxially prominent midrib that extends up to $6 \mathrm{~mm}$. Leaves: petiole 3-14 $\mathrm{cm}$ long, shorter towards the plant apex, terete, sparsely hairy; lamina suborbicular, asymmetric, 5-9.5 $\times 4-8 \mathrm{~cm}$, basifixed, base cordate with lobes slightly overlapping, adaxially green to reddish dark green, glossy, glabrous, abaxially pale green with hairs on veins only, primary veins $6-8$, actinodromous, margin fimbriate and recurved stiff teeth at the end of the veins, apex obtuse. Inflorescences axillary, cymose, branching 1-3 times, bisexual, 6-8 male flowers, 2-4 female flowers, protandrous; primary peduncle $c$. 7-12 cm long, glabrous; bracts semi-persistent, elliptic or narrowly obovate, $2.5-3.5 \times 1.5-2.5 \mathrm{~mm}$, margin fimbriate, apex acute. Male flowers: pedicel c. $12 \mathrm{~mm}$ long, glabrous; tepals 4; outer tepals suborbicular, 9-11 $\times$ 8-12.5 mm, white or white with pink stripes, glabrous, slightly cordate at the base becoming truncate when open, margin entire; inner tepals narrowly obovate or elliptic, 4-8 $\times 3-4 \mathrm{~mm}$, white; androecium pale yellow, symmetric, globose, stamens $c$. 40; filaments fused at base into a short column, $c .1-1.5 \mathrm{~mm}$ long; anther $0.75 \mathrm{~mm}$ long, obovate-obtriangular, dehiscing through slits slightly longer than half the length of the anther, apex retuse. Female flowers: pedicel 5-6 mm long; ovary green with red venation, glabrous, c. $7 \times 15$ including the wings; capsule ellipsoid, c. $7-8.5 \times 4.5-5 \mathrm{~mm}$, locules 3 , placentae entire; wings 3, equal, cuneate at base and apex, widest point at the middle, c. $4 \mathrm{~mm}$ wide; tepals 3 ; outer tepals 2, white or white with pink stripes, suborbicular, c. $6-7 \times 6.5-7.5 \mathrm{~mm}$; inner tepal elliptic, 5.5-6.5 $\times 1-2 \mathrm{~mm}$; stigmas 3, yellow, forked and once spirally twisted, caducous. Fruit recurved on a c. $6 \mathrm{~mm}$ long pedicel; wings the same as the ovary, capsule orbicular, $7.5 \times 5.5 \mathrm{~mm}$, total size $9 \times 18 \mathrm{~mm}$ including wings; apex obtuse.

\section{Distribution and habitat}

North Sumatra to Aceh, Gunung Leuser National Park at 200-300 m altitude (Fig. 2). The species grows terrestrially on soil over limestone slopes or directly on vertical limestone rock, half shade to full shade. Its distribution overlaps with that of B. olivacea, with which it hybridises (e.g. Puglisi et al. CP234, $\mathrm{BO}, \underline{\mathrm{E}})$.

\section{Conservation status}

The limestone habitat of the Gunung Leuser National Park in the Simolap area where this species occurs is relatively intact. As long as this remains the case, B. simolapensis can be considered as being Least Concern (IUCN 2012).

\section{Discussion}

Begonia sect. Bracteibegonia has a very conservative delimitation, with recently only three species recognised (Doorenbos et al. 1998), one new species added in 2009 (Hughes et al. 2009) and two transferred in 2011 (Hughes \& Girmansyah 2011a). The concept of the section has been further expanded here in the key to include 9 species from Sumatra. Where Begonia sect. Bracteibegonia ends and the allied very large Begonia sect. Petermannia starts is not clear at present, and a review of their delimitation across their range in the Malesian region is needed. This manuscript adds a further 2 species to Begonia sect. Bracteibegonia, taking the total to 10, all except one (Begonia lepida Blume (1827) from Java) are endemic to Sumatra. The authors concept of this section includes species with hairy stems, a low-growing spreading habit, leaves with short petioles, short peduncles and quite elongate 
fruits which often have bristles or hairs and persistent tepals. Many species from Borneo have this suite of characters and may need to be transferred to Begonia sect. Bracteibegonia following further research.

Sumatra is fast becoming a centre of diversity for Begonia sect. Reichenheimia, with 22 out of the total of 77 species in the section endemic to the island. The section encompasses a lot of morphological variation, and is distributed from Sri Lanka through India to China and into Southeast Asia (Doorenbos et al. 1998). The assignment of many species to Begonia sect. Reichenheimia has been done on a largely phenetic basis and relies on very few characters, usually a combination of stemless habit and fruit with non-divided placentae. Placental characters alone are not suitable for assigning species to section in Begonia, as they are homoplastic (Thomas et al. 2011), and stemless species can be either rhizomatous or tuberous, characters which have been overlooked up to now in terms of taxonomic utility. The tuberous type species of Begonia sect. Reichenheimia is B. tenera Dryand. (Dryander 1791) from Sri Lanka and molecular data (M. Hughes, unpublished data) shows it to have no affinity with the rhizomatous species from Southeast Asia including the new species published in this manuscript. However here we have followed the current consensus concept of Begonia sect. Reichenheimia for taxonomic convenience and stability, until we gather sufficient evidence for the splitting off of one or more new sections as natural groups.

Five out of the fifteen species described here are known only from material collected within the last 7 years. This shows how much there is still to be discovered in large genera such as Begonia which exhibit very high levels of micro-endemism, and highlights the need for further botanical exploration in Sumatra.

\section{Acknowledgements}

The authors are grateful for the support of the Indonesian Ministry of Research and Technology (Kementerian Riset dan Teknologi; RISTEK), the Indonesian Institute of Sciences (Lembaga Ilmu Pengetahuan Indonesia; LIPI), the Indonesian Forestry Department (Direktorat Jenderal Perlindungan Hutan dan Konservasi Alam; DITJEN PHKA), the Sibbald Trust, the M. L. MacIntyre Begonia Trust, the Royal Botanic Gardens Edinburgh Small Projects Fund, SYNTHESYS and the Davis Expedition Fund. Ahmad Taufiq, Riki Nova \& Nurainas are thanked for their expert assistance in the field, and the curators of ANDA, B, BM, BO, E, FI, K, L, P, SING for access to specimens. Two reviewers are thanked for their useful input in improving the manuscript. This research was carried out at the Royal Botanic Garden Edinburgh, supported by the Scottish Government's Rural and Environment Science and Analytical Services Division.

\section{References}

Agardh C.A. 1824. Aphorismi Botanici. Literis Berlingianis, Lundae [Lund]. http://dx.doi.org/10.5962/ bhl.title. 44857

Agardh C.A., Holmberg L.P. \& Lundstrom P.M. 1825. Classes Plantarum. Literis Berlingianis, Lundae [Lund]. http://dx.doi.org/10.5962/bhl.title.7657

Ardi W., Ardhaka I., Hughes M., Undaharta N., Girmansyah D. \& Hidayat S. 2013. Two new species of Begonia (Begoniaceae) from Bali and Lombok. Gardens' Bulletin Singapore 65 (2): 135-142.

Ardi W. \& Hughes M. 2010. Begonia droopiae Ardi (Begoniaceae), a new species of Begonia from West Sumatra. Gardens' Bulletin Singapore 62 (1): 19-24.

Averyanov L. \& Nguyen H. 2012. Eleven new species of Begonia L. (Begoniaceae) from Laos and Vietnam. Turczaninowia 15 (2): 5-32. 
Berchtold B.V. von \& Presl J.S. 1820. O přirozenosti rostlin, aneb rostlinářr, obsahugjcj: gedánj on žiwobytj rostlinném pro sebe a z ohledu giných žiwotů, podlé stawu nyněgssjho znánj; $k$ rozssjřenj přirodnictwj; $w$ potaženj na užitečnost $w$ rolnictwj, hospodářstwj, remeslech, uměnj i obchodu a $w$ wztahowánj obzwlásstnjm na lekařstwj. Enders, Prague.

Blume C.L. 1827. Enumeratio Plantarum Javae et insularum adjacentium minus cognitarum vel novarum ex herbariis Reinwardtii, Kuhlii, Hasseltii et Blumii curavit Carol. Ludov. Blume. Apud J.W. van Leeuwen, Lugduni Batavorum [Leiden]. http://dx.doi.org/10.5962/bhl.title.44901

Brown N.E. 1882. New garden plants. Gardener's Chronicle 18: 70-71.

Candolle A.L.P.P. de 1859. Mémoire sur la famille des Bégoniacées. Annales des sciences naturelles, Botanique, Sér 4, 11: 93-149.

Candolle A.L.P.P. de 1864. Begoniaceae. Prodromus Systematis Naturalis Regni Vegetabilis 15 (1): 266-408.

Chong F.Y., Guanih V.S., Sang J. \& Kiew R. 2015. Begonia (Begoniaceae) in the Danum Valley Conservation Area, Sabah, Borneo, including eleven new species. Sandakania 20: 51-85.

Doorenbos J., Sosef M.S.M. \& Wilde J.J.F.E. de 1998. The sections of Begonia including descriptions, keys and species lists. Wageningen Agricultural University Papers 98 (2). Wageningen Agricultural University, Wageningen.

Dryander J. 1791. Observations on the genus of Begonia. Transactions of the Linnean Society of London 1 (1): 155-173. http://dx.doi.org/10.1111/j.1096-3642.1791.tb00396.x

Girmansyah D. 2012. Two new species of Begonia (Begoniaceae) from Bukit Tigapuluh National Park, Riau, Sumatra. Reinwardtia 13 (3): 229-233.

Hughes M. 2008. An Annotated Checklist of Southeast Asian Begonia. Royal Botanic Garden Edinburgh, Edinburgh.

Hughes M. \& Girmansyah D. 2011a. A revision of Begonia sect. Sphenanthera (Hassk.) Warb. from Sumatra. Gardens' Bulletin Singapore 62 (2): 27-39.

Hughes M. \& Girmansyah D. 2011b. Searching for Sumatran Begonia described by William Jack: following in the footsteps of a 19th century Scottish botanist. Gardens' Bulletin Singapore 63 (1\&2): 83-96.

Hughes M., Girmansyah D., Ardi W.H. \& Nurainas. 2009. Seven new species of Begonia from Sumatra. Gardens' Bulletin Singapore 61 (1): 29-44.

Hughes M., Moonlight P.W., Jara A. \& Pullan M. 2015. Begonia Resource Centre [online]. Available from http://padme.rbge.org.uk/begonia [accessed 22 Jul. 2015].

Hughes M. \& Takeuchi W. 2015. A new section (Begonia sect. Oligandrae sect. nov.) and a new species (Begonia pentandra sp. nov.) in Begoniaceae from New Guinea. Phytotaxa 197 (1): 37-44. http://dx.doi. org/10.11646/phytotaxa.197.1.4

Hyam R., Drinkwater R.E. \& Harris D.J. 2012. Stable citations for herbarium specimens on the internet: An illustration from a taxonomic revision of Duboscia (Malvaceae). Phytotaxa 73: 17-30.

Irmscher E. 1913. Neue Begoniaceen Papuasiens mi einschluss von Celebes. Botanische Jahrbücher Fur Systematik, Pflanzengeschichte Und Pflanzengeographie 50: 335-383.

Irmscher E. 1929. Die Begoniaceen der Malaiischen Halbinsel. Mitteilungen Aus Dem Institut Für Allgemeine Botanik in Hamburg 8: 87-160. 
Irmscher E. 1954. Neue Begoniaceen von O. Beccari in Malesien gesammelt. Webbia 9 (2): 469-505. http://dx.doi.org/10.1080/00837792.1954.10669621

IUCN 2012. IUCN Red List Categories and Criteria: Version 3.1. Second Edition. IUCN, Gland, Switzerland and Cambridge, UK.

Jack W. 1822. Descriptions of Malayan plants. Malayan Miscellanies 2 (7): 1-96.

Jansson C.-A. 1963. Eine neue Begonia aus Indonesien. Acta Horticulturae Gothoburgensis 26: 1-4.

Kelman C.C. 2013. Governance lessons from two Sumatran integrated conservation and development projects. Conservation \& Society 11 (3): 247-263. http://dx.doi.org/10.4103/0972-4923.121028

Kiew R. 2005. Begonias of Peninsular Malaysia. Natural History Publications (Borneo), Kota Kinabalu.

King G. 1902. Materials for a flora of the Malay Peninsula. The Journal of the Asiatic Society of Bengal 71: 46-80.

Koorders S.H. 1912. Exkursionsflora von Java Umfassend die Blütenpflanzen mit Besonderer Berücksichtigung der im Hochgebirge Wildwachsenden Arten im Auftrage des Niederländischen Kolonialministeriums Bearbeitet. II. Jena, Germany.

Linnaeus C. 1753. Species plantarum: exhibentes plantas rite cognitas, ad genera relatas, cum differentiis specificis, nominibus trivialibus, synonymis selectis, locis natalibus, secundum systema sexuale digestas. Laurentii Salvii, Holmiae [Stockholm]. http://dx.doi.org/10.5962/bhl.title.669

Merrill E.D. \& Quisumbing E. 1932. Begonia wadei. Addisonia 17: 57-58.

Miquel F.A.W. 1855. Plantae Junghuhnianae. A.W. Sythoff, Lugduni-Batavorum [Leiden]. http:// dx.doi.org/10.5962/bhl.title. 388

Miquel F.A.W. 1856. Flora van Nederlandsch Indie i. I. C.G. van der Post, Amsterdam.

Ridley H.N. 1894. Begonia rajah. Gardener's Chronicle 16: 213.

Ridley H.N. 1917. New and rare Malayan plants. Series IX. Journal of the Straits Branch of the Royal Asiatic Society 75: 5-38.

Ridley H.N. 1923. A botanical excursion to northern Sumatra. Journal of the Royal Asiatic Society, Malayan Branch 87: 46-113.

Ridley H.N. 1925. Plants from Bencoolen, Sumatra. Collected by Mr. C. J. Brooks. Bulletin of Miscellaneous Information, Royal Botanic Gardens, Kew 1925: 76-94.

Sang J., Kiew R. \& Geri C. 2013. Revision of Begonia (Begoniaceae) from the Melinau Limestone in Gunung Mulu National Park and Gunung Buda National Park, Sarawak, Borneo, including thirteen new species. Phytotaxa 99 (1): 1-34. http://dx.doi.org/10.11646/phytotaxa.99.1.1

Sang J., Kiew R. \& Yiing L.C. 2015. A decade of Begonia (Begoniaceae) from Borneo. Sandakania 20: $129-154$.

Smith L.B. \& Wasshausen D.C. 1984. Notes on Begoniaceae III. Phytologia 54: 465-473.

Takhtajan A.L. 1967. Sistema ifilogeniia tsvetkovykh rastenii (Systema et Phylogenia Magnoliophytorum). Soviet Science Press, Moscow.

Tebbitt M.C. 2005. A new species of fleshy-fruited Begonia (Begoniaceae) from Sumatra. Blumea 50 (1): 153-156. http://dx.doi.org/10.3767/000651905X623337

Tebbitt M.C. \& Dickson J.H. 2000. Amended descriptions and revised sectional assignment of some Asian begonias (Begoniaceae). Brittonia 52 (1): 112-117. http://dx.doi.org/10.2307/2666496 
Thomas D.C., Hughes M., Phutthai T., Rajbhandary S., Rubite R., Ardi W.H. \& Richardson J.E. 2011. A non-coding plastid DNA phylogeny of Asian Begonia (Begoniaceae): evidence for morphological homoplasy and sectional polyphyly. Molecular Phylogenetics and Evolution 60 (3): 428-444. http:// dx.doi.org/10.1016/j.ympev.2011.05.006

Warburg O. 1894. Begoniaceae. In: Engler A. \& Prantle K. (eds) Die Natürlichen Pflanzenfamilien 3, 6A: 121-150. Englemann, Leipzig.

Manuscript received: 22 January 2015

Manuscript accepted: 28 October 2015

Published on: 21 December 2015

Topic editors: Thomas Janssen \& Koen Martens

Desk editor: Natacha Beau

Printed versions of all papers are also deposited in the libraries of the institutes that are members of the EJT consortium: Muséum national d'Histoire naturelle, Paris, France; Botanic Garden Meise, Belgium; Royal Museum for Central Africa, Tervuren, Belgium; Natural History Museum, London, United Kingdom; Royal Belgian Institute of Natural Sciences, Brussels, Belgium; Natural history Museum of Denmark, Copenhagen, Denmark. 